\title{
Personality traits, preferences and educational choices: a focus on STEM
}

Citation for published version (APA):

Coenen, J., Borghans, L., \& Diris, R. (2021). Personality traits, preferences and educational choices: a focus on STEM. Journal of Economic Psychology, 84, [102361]. https://doi.org/10.1016/j.joep.2021.102361

Document status and date:

Published: 01/06/2021

DOI:

10.1016/j.joep.2021.102361

Document Version:

Publisher's PDF, also known as Version of record

Document license:

Taverne

Please check the document version of this publication:

- A submitted manuscript is the version of the article upon submission and before peer-review. There can be important differences between the submitted version and the official published version of record.

People interested in the research are advised to contact the author for the final version of the publication, or visit the DOI to the publisher's website.

- The final author version and the galley proof are versions of the publication after peer review.

- The final published version features the final layout of the paper including the volume, issue and page numbers.

Link to publication

\footnotetext{
General rights rights.

- You may freely distribute the URL identifying the publication in the public portal. please follow below link for the End User Agreement:

www.umlib.nl/taverne-license

Take down policy

If you believe that this document breaches copyright please contact us at:

repository@maastrichtuniversity.nl

providing details and we will investigate your claim.
}

Copyright and moral rights for the publications made accessible in the public portal are retained by the authors and/or other copyright owners and it is a condition of accessing publications that users recognise and abide by the legal requirements associated with these

- Users may download and print one copy of any publication from the public portal for the purpose of private study or research.

- You may not further distribute the material or use it for any profit-making activity or commercial gain

If the publication is distributed under the terms of Article $25 \mathrm{fa}$ of the Dutch Copyright Act, indicated by the "Taverne" license above, 


\title{
Personality traits, preferences and educational choices: A focus on STEM ${ }^{2}$
}

\author{
Johan Coenen $^{\mathrm{a}, *}$, Lex Borghans ${ }^{\mathrm{b}}$, Ron Diris ${ }^{\mathrm{c}}$ \\ ${ }^{a}$ CINOP-ECBO, the Netherlands \\ ${ }^{\mathrm{b}}$ School of Business and Economics, Maastricht University, the Netherlands \\ ${ }^{\mathrm{c}}$ Faculty of Law, Leiden University, the Netherlands
}

\section{A R T I C L E I N F O}

\section{JEL classification::}

I20

I21

$\mathrm{J} 24$

Keywords:

Personality

Educational choice

STEM

PsycINFO classification::

3580

3610

\begin{abstract}
A B S T R A C T
Around the developed world, the need for graduates from Science, Technology, Engineering and Mathematics (STEM) fields is growing. Research on educational and occupational choice has traditionally focused on the cognitive skills of prospective students, and on how these determine the expected costs and benefits of study programs. Little work exists that analyzes the role of personality traits on study choice. This study investigates how personality traits relate to preferences of students for STEM studies and occupations, and to specialization choice in high school. We use a rich data set that combines administrative and survey data of Dutch secondary education students. We find that personality traits are related to both the preference that students have for STEM as the actual decision to specialize in STEM studies, but to different degrees. We identify significant relations with preference indicators for all Big Five traits, especially for Openness to Experience (positive), Extraversion and Agreeableness (both negative). The size of these relations is often larger than those between cognitive skills and STEM preferences. Personality traits are comparatively less important with respect to the actual specialization choice, for which we identify a robust (and sizable) negative relation with Extraversion, and for girls find a positive relation with Openness to Experience. The results suggest that once students have to make actual study choice decisions, they rely more on cognitive skills rather than personality traits, in contrast to their expressed preferences.
\end{abstract}

\section{Introduction}

The demand for graduates from Science, Technology, Engineering and Mathematics (STEM) fields has been growing around the developed world, with a further increase expected in the near future (ICF \& Cedefop, 2015). STEM fields are important drivers of innovation (Atkinson \& Mayo, 2010). Consequently, it is often argued that large shortages in STEM graduates hamper economic growth (Carnevale, Smith, \& Melton, 2011). While the number of graduates in STEM fields has been increasing somewhat, it does not

The research was funded by the Dutch Science Organization through grant 407-12-004, project title 'Attracting and retaining top talent for the High Tech Systems and materials'. We would like to thank the participants from the Workshop on Dynamics of Skills Supply and Demand 2018, LESE 2019 and LEER 2019 for their valuable comments. The data and codes to replicate the analyses of this paper can be found here: https://doi. org/10.17632/vt5v7c27kw.1

* Corresponding author.

E-mail addresses: Johan.Coenen@ecbo.nl (J. Coenen), lex.borghans@maastrichtuniversity.nl (L. Borghans), r.e.m.diris@law.leidenuniv.nl (R. Diris). 
cover the rising demand for professionals in STEM occupations. In the United States, the STEM workforce has increased by 3 to $4 \%$ each year between 1990 and 2007, while the number of graduates from STEM fields has only grown by $2 \%$ per year over the same period (Atkinson \& Mayo, 2010). In response to this perceived excess demand for STEM graduates, encouraging more students to enroll in STEM study programs is high on the political agenda.

Encouraging STEM enrollment requires an understanding of what determines study field choice. The academic literature on explaining educational and occupational choice has traditionally focused on differences in expected costs and benefits of study programs, which are typically mediated by student ability, measured by cognitive skills, and family background (Fuller, Manski, \& Wise, 1982; Schwartz, 1985). Student preferences for different study fields are usually incorporated in such models as well, but are typically unobserved by the researcher. More recently, studies have focused on how the provision of labor market information related to the study choice affects beliefs about expected net returns, and consequent study choices as well (Jensen, 2010; Arcidiacono, Hotz, \& Kang, 2012). Where such studies on educational choice are largely centered around cognitive ability, the influence of personality traits on educational and occupational choice has not received much attention. Personality traits can be relevant for study choice for several reasons. They can directly affect the expected net return for different studies. It is well-documented that personality is strongly related to labour market outcomes (Heckman, Stixrud, \& Urzua, 2006). Additionally, personality traits could determine preferences for field of study, also net of their labour market return.

This paper investigates whether Big Five personality traits are related to preferences for STEM studies and occupations as well as the specialization choice for STEM in upper secondary education. We investigate how the Big Five personality factors are related to preferences for future studies and occupations and for the probability of secondary education students to enroll into STEM specializations in high school. We make use of a rich data set which combines administrative and survey data of Dutch secondary education students in the province of Limburg. The data allow us to directly observe preferences for study and occupation, as well as measures of cognitive skills and personality traits. This enables us to relate personality traits and cognitive ability to the choice of a STEM study program ranging from preference for STEM in primary education, to preferences for a STEM occupation and for a STEM field of study in lower secondary education up until choosing the Science \& Technology track in upper secondary education.

We find that personality traits are related to both the preference students have for STEM as the actual decision to pursue higher education in STEM. All of the Big Five traits are significantly related to preferences for STEM study fields or STEM occupations, and some to both. These relations are strongest for Openness to Experience (positive), Extraversion and Agreeableness (both negative). Standardized effect sizes for these traits are around $0.10-0.15$ of a standard deviation, which is above the estimated relation with nonverbal IQ. With respect to the actual educational choice to specialize in STEM, we identify a robust significant relation with respect to Extraversion (22-25 percent more STEM specialization for one standard deviation increase in Extraversion). Furthermore, for girls we find evidence of a positive relation with Openness to Experience. When we use earlier measures of the Big Five traits, we find a more sizable relation between Openness to Experience and STEM specialization.

Thus, it appears that personality traits are important in shaping the preferences of students towards study fields and occupations, but when students face the decision to specialize they are guided more by cognitive skills rather than by personality traits, with the exception of Extraversion. The relation with Extraversion is nonetheless sizable; its association with STEM specialization choice is at the same level as that of non-verbal IQ.

The remainder of the paper is structured as follows. In Section 2, we discuss the relevant literature on study choice and personality. Section 3 explains the institutional setting of Dutch education. In Section 4, the estimation strategy is discussed. Section 5 describes the data and provides descriptive statistics, after which Section 6 discusses the results. Section 7 addresses the robustness of our estimates, after which Section 8 concludes.

\section{Literature}

There exists a large literature on the determinants of college major choice. Part of the literature focuses on the influence of expected earnings. Early work by Berger (1988) shows that students are forward looking and take expected earnings into account. The majority of recent studies find a significant but modest elasticity between college major choice and expected earnings, see for example Beffy, Fougere, and Maurel (2012), Wiswall and Zafar (2014) and Long, Goldhaber, and Huntington-Klein (2015).

Other studies focus on the role of perceived ability on college major choice. Arcidiacono (2004) finds that cognitive ability is an important determinant of college major choice, and mathematics ability especially so. Fricke, Grogger, and Steinmayr (2015) find that first-year exposure to certain fields of study in college affects later college major choice. They exploit a natural experiment in Switzerland, where first-year students are randomly assigned to write a research paper in either business, economics or law. Assignment to the economics treatment group increased economics major choice substantially.

Another branch of this literature focuses on the considerable differences in study choice between boys and girls. Gemici and Wiswall (2014) find that differences in tastes/preferences are more important for explaining disparities than differences in skills. They additionally find that, because of higher expected future labour supply, males have been more responsive to the increase in demand for science and business degrees in the 1980's and 1990's, leading to a widening of the gender gap in major choice. Breda and Napp (2019), on the other hand, finds that girls' comparative advantage in language versus math can explain a large share of sex differences in declared interest for math. Nonetheless, strong sex differences in STEM raise the potential importance of how social norms can shape differences in preferences by sex, and by other indicators such as ethnicity and social class. A growing literature examines the processes and institutions that may shape these different preferences; see, e.g., Kahn and Ginther (2017, 2015, 2000). It is not the aim of this study to explain such gaps, but we do analyze how the relation between STEM and personality differs between boys and girls.

A common factor across studies that relate ability to major choice is that ability is measured by cognitive skills, typically through 
test scores or GPA. Research in both psychology and economics has well-documented the importance of personality traits for later-life outcomes, such as educational attainment, labor market success, health and life satisfaction (Almlund, Duckworth, Heckman, \& Kautz, 2011; Roberts, Kuncel, Shiner, Caspi, \& Goldberg, 2007). The most-commonly used taxonomy for personality in these studies is the Five Factor Model, also commonly known as the Big Five (Costa \& McCrae, 1992). Of these five factors, Conscientiousness is identified as the Big Five trait with the largest and most diverse predictive power, across a wide range of different outcomes. Conscientiousness, Openness and Neuroticism are especially relevant for educational outcomes (Goldberg, Sweeney, Merenda, \& Hughes, 1998; Van dean Eijck \& de Graaf, 2004; Almlund et al., 2011). The predictive power of Conscientiousness is especially large with respect to course grades (Borghans, Golsteyn, Heckman, \& Humphries, 2011; Poropat, 2009). Other studies show the strong predictive power of Conscientiousness, Agreeableness and Neuroticism, as well as of other personality traits such as locus of control and withdrawal, towards the wages of both men and women, see, e..g., Nyhus and Pons (2005, 2005). Some recent studies however argue that the effect of personality traits on wages mainly operates through educational attainment (Heckman, Humphries, Urzua, \& Veramendi, 2011). Cognitive skills appear comparatively more important for job performance: while Conscientiousness is the strongest predictor of job performance among the Big Five, it is only half as predictive as IQ, which is especially relevant for more complex tasks Barrick and Mount (1991, 1998, 2011).

There are still few studies that relate personality to study choice. Research on the relation between personality and occupational choices are relatively more common. Personality has been studied with respect to choices for IT jobs (Rosenbloom, Ash, Dupont, \& Coder, 2008), for white-collar versus blue-collar jobs (Ham, Junankar, \& Wells, 2009), and for explaining gender wage gaps within MBA's (Grove, Hussey, \& Jetter, 2011). Additionally, there exists an extensive literature on the relation between vocational interest and personality. The theory of "vocational personality" was posited by Holland (1959, 1997). Among others, De Fruyt and Mervielde (1997) have shown that Holland's personality types relate to Big Five traits. More specifically, Chen and Simpson (2015) provide estimates of the relation between vocational interest and STEM. They find that those who select STEM have a more investigative and a less artistic personality. Having a social personality is negatively related to STEM choice for boys, but not for girls.

Three studies relate more closely to our analysis, as they also specifically look at the relation between Big Five personality and STEM choices. Cobb-Clark and Tan (2011) use Australian data to estimate the predictive power of personality towards 18 different occupational categories, of which two relate to Science and Technology. For these categories, they identify statistically significant relations with Openness (positive) and Neuroticism (negative). Personality traits are more predictive for working in these fields for women than for men. The main goal of Cobb-Clark and Tan (2011) is to assess whether personality traits can explain differences in occupational sorting by gender (for which they do not find strong evidence). Humburg (2017) uses Dutch data to link Big Five measures to major choice in university, and identifies a negative relation between STEM choice and Neuroticism and, especially, Extraversion. Finally, Balsamo, Lauriola, and Saggino (2012) analyzes group differences in Big Five traits across college majors for a sample of 886 Italian students. They find that, after controlling for school type and gender, only Extraversion is a significant predictor of personality differences across majors, with those in Natural Sciences being somewhat more introvert. Our study adds to this still scarce literature, and is the first to consider the role of personality for both STEM preferences and STEM study choice. Additionally, we use rich longitudinal data with measures of personality and preferences at different ages and an extensive set of (potentially confounding) cognitive indicators, and consider how measurement error may affect the identified relations.

\section{Institutional setting}

We study STEM choice in the context of the Netherlands. Fig. 1 displays the educational system of the Netherlands. We focus on the secondary school students from Upper Secondary General Education (HAVO), which prepares students for Higher Vocational Education, and Pre-university Education (VWO), which prepares students for University. VWO has two subtracks: Atheneum and Gymnasium. The main difference is that at Gymnasium students also get Latin and Greece. In the first three years of secondary education, all students follow a general curriculum that is identical within each track. After the third year of secondary education, students have to choose a specialization with respect to the set of subjects they want to follow in upper secondary education. Four specializations are available: (1) Science \& Technology; (2) Nature \& Health, (3) Economics \& Society, and (4) Culture \& Society. ${ }^{1}$ Students already presort for certain fields of study in higher education with this specialization choice. The Science \& Technology specialization is designed to be preparatory for post-secondary studies in STEM, because of its focus on the subjects mathematics, physics and chemistry. Most post-secondary study programs in STEM require students to have finished this preparatory specialization. Students who choose to enroll into Nature \& Health are likely to head towards a Medicine or Health sciences study program. The other two specializations are preparatory for fields of study such as Economics, Business, Languages, and Humanities and Arts. In contrast to colleges and universities in, for example, the United States, post-secondary study programs in the Netherlands are already narrowed down. This could be compared with choosing a major in the United States, but rather from the first year onward.

Statistics Netherlands reports that, in 2007, two-thirds of the students who followed the S\&T specialization went on to a STEM field of study in higher education (CBS, 2007). More recent data is only available for the combination of the students of Science \& Technology and Nature \& Health. These data, which naturally are lower because of the large share of students specializing for Health studies, show a modest increase in the last decade in both the share of students choosing one of the two specializations and the share of students with any of the two specializations that also enrolls in STEM studies in higher education (Techniekpactmonitor, 2019). Hence,

\footnotetext{
${ }^{1}$ Apart from specialization courses and (typically two) electives, all students have to complete exams in (Dutch) Language, English, a second foreign language, and social science.
} 


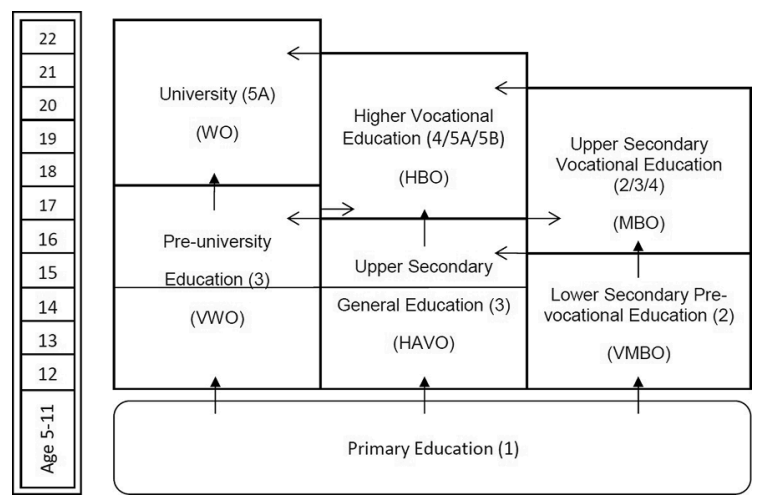

Fig. 1. The Dutch education system. Note: ISCED level in parentheses.

we may consider the figures for 2007 as a lower bound estimate of the current transition rate, and can conclude that a considerable share of the students in this S\&T specialization continue a STEM education.

After two years in Upper Secondary General Education students take their final exams. After passing these exams and consequently acquiring a diploma, they can enroll into a Higher Vocational Education study program. The students in Pre-university education spend three years in higher secondary education before their final exams. After graduation, they are eligible to enroll into university programs. Many study programs require prospective students to have passed exams in specific subjects, either as part of their specialization or as an elective.

\section{Identification and estimation model}

Our goal is to estimate the relevance of personality traits towards both preferences for STEM and choice for STEM specialization. As a first indication of students' STEM preference, we regress whether students have a preference for working in a STEM occupation in the future on ability measures, personality traits and student background characteristics:

$$
P_{i}=\alpha_{0}+P T_{i}^{\prime} \alpha_{1}+A_{i}^{\prime} \alpha_{2}+X_{i}^{\prime} \alpha_{3}+\epsilon_{i}
$$

$P_{i}$ measures the preference for a STEM occupation, and is measured on a Likert scale from 1 to 5 . We therefore estimate an ordered logit model. Similarly, we estimate the same specification using students' preferences for a STEM field of study. We use an OLS model in this particular case, as this measure of $P_{i}$ is a standardized sum score based on responses to 11 items. $P T$ are indicators for the Big Five factors. $A$ is a vector of ability measures of students, and $X$ are student and family background characteristics. Ability is proxied by (1) track in secondary education, (2) student performance on an IQ test (3 components: figures, numbers and words), (3) student performance on a mathematics test and, (4) student performance on a reading test. Student and family characteristics include sex, parental education (father) and ethnicity.

Additionally, we estimate relations towards the actual choice of specializing in STEM in high school. We estimate the probability of students to enroll into this track by:

$$
S T_{i}=\alpha_{0}+P T_{i}^{\prime} \alpha_{1}+A_{i}^{\prime} \alpha_{2}+X_{i}^{\prime} \alpha_{3}+\epsilon_{i}
$$

in which ST equals 1 if a student enrolls into the Science \& Technology track and 0 otherwise. We use a logit specification for this outcome.

\section{Data \& descriptive statistics}

\subsection{Data $^{2}$}

We use data from the Education Monitor Limburg (Onderwijsmonitor Limburg, or OML), which collects administrative data registered by primary and secondary schools, takes additional cognitive tests and collects student and parental data via questionnaires. Almost all primary and secondary schools in the province of Limburg in the Southeast of the Netherlands participate in the OML. The data collections take place in grade 6 , the final year of primary education, and in grade 9 , the third year of secondary education, in which students choose their specialization for upper secondary education. OML data is collected annually in grade 6 and biannually in grade 9. The data collection is approved by the local ethical committee (ERCIC-092-12-07-2018). We use data on the 2009 primary education cohort and the 2012 secondary education cohort (which to a large extent are the same students at different ages).

${ }^{2}$ More detailed information on data sources and measures is provided in Web Appendix A. 
The Big Five indicators are collected in both grade 6 and grade 9. The items are selected from a Dutch translation of the 50-item IPIP representation of theGoldberg (1992) markers for the Big-Five factor structure. The IPIP personality inventory has been used and validated in research across different cultural contexts and ages. For every factor of the Big Five taxonomy the four simultaneously most predictive items were selected using data from the 2009 DNB Household Survey.

We use two measures of STEM preferences. One is an occupational preference measure, based on one item that asks students on a 15 Likert scale their likelihood of working in a STEM profession in the future. ${ }^{3}$ The other is a measure of STEM study preference, relying on linked data from a questionnaire for study choice counseling, administered by an external bureau. The test adapts the work of Liao, Armstrong, and Rounds (2008) to the Dutch labour market. It consists of 198 items, of which 11 are directed towards STEM interest. See Web Appendix A for more detail.

We note that our STEM occupational preference measure is essentially a self-estimated likelihood of working in a STEM profession. It is therefore likely to incorporate self-assessed ability and external circumstances as well (although this likely applies to any concrete measure of preference). We label both measures as preferences in the remainder of the paper, with these caveats in mind. Results can reveal to what extent this conceptual difference matters for the relation towards personality traits. Moreover, estimations control for cognitive ability, among other factors, and therefore it is plausible that the remaining variation is dominated by individual preferences. 4

The OML also administers tests for IQ in grade 6 and for IQ, mathematics and reading in grade 9. The grade 6 IQ test contains 43 items and the grade 9 test contains 25 items. Each test is identical for all students. The 9th grade math and language tests contain different versions for the different tracks, with overlapping items. On average, students receive 23 mathematics questions and 24 reading questions. All test scores are standardized sum scores of the number of questions completed. Differences in the difficulty levels of the versions are captured by the track fixed effects. In an alternative approach, we use IRT to create scores that are comparable across tracks. This leads to very similar results. The assignment of math and language tests was randomized: one third of the students took only the math test, one third only the language tests and one third took both tests. This means that the share of students with scores on both tests is relatively small, and our most complete specifications are therefore based on smaller samples. As a robustness check, we will estimate our models with SEM using FIML (Full Information Maximum Likelihood), to determine to what extent differences between our models are caused by the reduced sample, rather than by the addition of the mathematics and/or reading achievement scores as control variables. Finally, the OML data contains subjective measures of students' self-confidence in a range of different skills, including arithmetic (measured on a scale from 1-5). We include this measure in extended specifications of our model, in order to assess whether subjective beliefs about the own ability are potential drivers of results, over and above objective measures of cognitive skills.

\subsection{Descriptive statistics}

The differences between students that do and students that do not choose the S\&T track are of a similar size with respect to IQ (0.302) and mathematics (0.385) scores. The difference in IQ is largest for the non-verbal aspects of the IQ test. The difference in reading performance is very small and not statistically significant: 0.027 SD. Students who choose the S\&T track also have substantially more confidence in their own level of arithmetic. To sum up, there are differences between students who choose the Science \& Technology track and students who do not, in cognitive skills, personality traits and in self-confidence.(see Table 1)

Table 2 shows a similar comparison, now across indicators of background and track. The table shows that boys are far more likely to choose the Science \& Technology track than girls: $27 \%$ of all male students chooses this track, while the same holds for only $7 \%$ of the female students. Strong sex differences in STEM choice are a consistent finding across the world (see, e.g., OECD (2016)), and this sample is thus no exception.

The higher the level of secondary education students are in, the more likely students are to choose the Science \& Technology track. At the Havo level, only 14\% of the students opts for the S\&T track. In Atheneum, this percentage goes up to 19\%, while in Gymnasium, $24 \%$ of the students choose to enter the Science \& Technology track. Only $12 \%$ of students with a non-western immigrant background choose the S\&T track. Lastly, the higher the paternal education level, the more likely students are to opt for the S\&T track. See Web Appendix A for a correlation table with all the variables of the analysis.

\section{Results}

In every analysis we estimate six versions of our model: In the first step, we only include the indicators of the Big Five. In the second step we add student characteristics: sex, the current level of the students (havo, atheneum or gymnasium) and dummy variables to control for the students' ethnicity and parental education (paternal). In the third step we add the perceived ability in mathematics (confidence in arithmetic). In the fourth step, we add the three subscores of the IQ test. In the fifth step, we add the mathematics achievement test score. Finally, in the sixth step, we add the reading test score. Note that the number of observations decreases

\footnotetext{
${ }^{3}$ The occupational preference measure is based on a single item from the student questionnaire and thus does not rely on any established measure. We recognize that this can induce higher standard errors for effect sizes in those regressions.

${ }^{4}$ The counseling test is not taken by all students in the OML population. This subset contains relatively more students from the top Gymnasium track. Parental education and math scores are slightly higher, but IQ scores and personality traits are highly similar to the main sample. We analyze the potential implications of these differences in sample size in Section 6 .
} 
Table 1

Descriptive statistics: personality and ability (S\&T students vs. all other students).

\begin{tabular}{|c|c|c|c|c|c|}
\hline & \multicolumn{2}{|c|}{ S\&T } & \multicolumn{2}{|c|}{ Other tracks } & \multirow[t]{2}{*}{ Difference } \\
\hline & Mean & $\mathrm{N}$ & Mean & $\mathrm{N}$ & \\
\hline \multicolumn{6}{|l|}{ Personality traits } \\
\hline Openness & 0.311 & 590 & 0.180 & 2887 & $0.131 * *$ \\
\hline Conscientiousness & 0.028 & 590 & -0.002 & 2887 & 0.030 \\
\hline Extraversion & -0.268 & 590 & 0.093 & 2887 & $-0.362^{* * *}$ \\
\hline Agreeableness & -0.112 & 590 & 0.200 & 2887 & $-0.313^{* * *}$ \\
\hline Neuroticism & -0.270 & 590 & -0.012 & 2887 & $-0.258 * * *$ \\
\hline \multicolumn{6}{|l|}{ Ability measures } \\
\hline IQ total & 0.757 & 568 & 0.455 & 2775 & $0.302^{* * *}$ \\
\hline IQ figures & 0.557 & 568 & 0.283 & 2775 & $0.275^{* * *}$ \\
\hline IQ numbers & 0.689 & 568 & 0.381 & 2775 & $0.308^{* * *}$ \\
\hline IQ words & 0.342 & 568 & 0.220 & 2775 & $0.122 *$ \\
\hline Mathematics test & 0.796 & 423 & 0.411 & 1990 & $0.385^{* * *}$ \\
\hline Reading test & 0.279 & 415 & 0.252 & 2109 & 0.027 \\
\hline Confidence in arithmetic & 7.747 & 580 & 6.753 & 2851 & $0.994 * * *$ \\
\hline
\end{tabular}

Note: $*=$ significant at the .05 level. ${ }^{* *}=$ significant at the .01 level. ${ }^{* * *}=$ significant at the .001 level.

Table 2

Descriptive statistics: background variables.

\begin{tabular}{|c|c|c|c|}
\hline & $\% \mathrm{~S} \& \mathrm{~T}$ & $\%$ of sample & $\mathrm{N}$ \\
\hline \multicolumn{4}{|l|}{$\operatorname{Sex}$} \\
\hline Boys & 27.48 & 47.53 & 1634 \\
\hline Girls & 7.32 & 52.47 & 1804 \\
\hline \multicolumn{4}{|l|}{ Track } \\
\hline Havo & 14.13 & 48.66 & 1692 \\
\hline Atheneum & 18.53 & 40.81 & 1419 \\
\hline Gymnasium & 24.04 & 10.53 & 366 \\
\hline \multicolumn{4}{|l|}{ Origin } \\
\hline Province of Limburg & 16.61 & 75.15 & 2601 \\
\hline Rest of the Netherlands & 20.04 & 16.15 & 559 \\
\hline Immigrant from western country & 17.07 & 3.55 & 123 \\
\hline Immigrant from non-western country & 12.36 & 5.14 & 178 \\
\hline \multicolumn{4}{|l|}{ Parental education (father) } \\
\hline Primary education & 13.64 & 1.32 & 44 \\
\hline Lower secondary pre-vocational education & 15.16 & 28.19 & 943 \\
\hline Upper secondary vocational/general education & 15.91 & 27.80 & 930 \\
\hline Higher vocational education & 18.21 & 23.32 & 780 \\
\hline University & 18.52 & 19.37 & 648 \\
\hline
\end{tabular}

Note: '\% S\&T' shows the share of each group that chooses the Science and Technology specialization. '\% of sample' shows the fraction of the sample that each group represents.

substantially in models 5 and 6, because only (randomly) selected students make both tests.

\subsection{Occupational preferences for STEM}

We first present results for the ordered logit model with respect to preferences for a STEM occupation in grade 9, shown in Table 3 .

We can draw several conclusions from Table 3. Openness to Experience, Agreeableness and Extraversion are the strongest Big Five predictors of preferences for a STEM occupation. For Openness and Agreeableness, a sizable part of the initial association in the most simple model (1) is driven by sex and track, but the relationship remains strongly statistically significant in more extensive models, and is very stable from Models 2 through 6. For Extraversion, part of the initial association is driven by differences in cognitive ability. The magnitude of the coefficients is very similar between these three indicators. Using the odds ratios, an increase of one standard deviation (SD) on the Openness scale is associated with around a $20 \%$ increase in the odds of having a high value for STEM occupational preferences. These associations equal around $21 \%$ and $22 \%$ for Agreeableness and Extraversion, respectively, in the opposite direction. Conscientiousness might also be related to preferences for a STEM occupation, but, after controlling for ability measures, is only significant in the most complete model (about 11\%). Lastly, the measure for Neuroticism is only statistically significant and negative in the reduced models 1-3, but insignificant once the ability measures are included in models 4-6.

Results for the background variables show that sex has the strongest association with the preference for working in a STEM occupation. IQ and mathematics test scores are positively related to preference for working in a STEM occupation, while the opposite holds for reading test scores. The latter result holds conditional on IQ and math scores and is therefore rather an indicator of 
Table 3

Ordered logit estimates STEM occupational preference (grade 9).

\begin{tabular}{|c|c|c|c|c|c|c|}
\hline & (1) & (2) & (3) & (4) & (5) & (6) \\
\hline \multirow[t]{2}{*}{ Openness } & $0.328^{* * *}$ & $0.210^{* * *}$ & $0.196^{* * *}$ & $0.192^{* * *}$ & $0.174^{* * *}$ & $0.182^{* *}$ \\
\hline & $(0.037)$ & $(0.039)$ & $(0.039)$ & $(0.040)$ & $(0.048)$ & $(0.058)$ \\
\hline \multirow[t]{2}{*}{ Conscientiousness } & $0.072 *$ & $0.103^{* *}$ & 0.063 & 0.069 & 0.068 & $0.104 *$ \\
\hline & $(0.033)$ & $(0.034)$ & $(0.035)$ & $(0.036)$ & $(0.043)$ & $(0.052)$ \\
\hline \multirow[t]{2}{*}{ Extraversion } & $-0.354 * * *$ & $-0.309^{* * *}$ & $-0.310^{* * *}$ & $-0.290 * * *$ & $-0.256^{* * *}$ & $-0.196^{* * *}$ \\
\hline & $(0.035)$ & $(0.036)$ & $(0.037)$ & $(0.038)$ & $(0.044)$ & $(0.052)$ \\
\hline \multirow[t]{2}{*}{ Agreeableness } & $-0.348^{* * *}$ & $-0.221 * * *$ & $-0.215^{* * *}$ & $-0.230^{* * *}$ & $-0.239^{* * *}$ & $-0.237^{* * *}$ \\
\hline & $(0.041)$ & $(0.044)$ & $(0.044)$ & $(0.045)$ & $(0.054)$ & $(0.065)$ \\
\hline \multirow[t]{2}{*}{ Neuroticism } & $-0.255^{* * *}$ & $-0.128^{* * *}$ & $-0.077^{*}$ & -0.059 & -0.071 & -0.078 \\
\hline & $(0.035)$ & $(0.037)$ & $(0.038)$ & $(0.039)$ & $(0.045)$ & $(0.056)$ \\
\hline \multirow[t]{2}{*}{ Female } & & $-0.903^{* * *}$ & $-0.772^{* * *}$ & $-0.807^{* * *}$ & $-0.834^{* * *}$ & $-0.845^{* * *}$ \\
\hline & & $(0.073)$ & $(0.075)$ & $(0.076)$ & $(0.090)$ & $(0.112)$ \\
\hline \multirow[t]{2}{*}{ Atheneum } & & $0.337 * * *$ & $0.269^{* * *}$ & 0.133 & -0.020 & 0.098 \\
\hline & & $(0.071)$ & $(0.072)$ & $(0.076)$ & $(0.092)$ & $(0.120)$ \\
\hline \multirow[t]{2}{*}{ Gymnasium } & & $0.425^{* * *}$ & $0.336 * *$ & 0.173 & 0.111 & $0.326^{*}$ \\
\hline & & $(0.112)$ & $(0.113)$ & $(0.119)$ & $(0.144)$ & $(0.185)$ \\
\hline \multirow[t]{2}{*}{ Confidence in arithmetic } & & & $0.209 * * *$ & $0.185^{* * *}$ & $0.154 * * *$ & $0.132^{* * *}$ \\
\hline & & & $(0.020)$ & $(0.021)$ & $(0.024)$ & $(0.029)$ \\
\hline \multirow[t]{2}{*}{ IQ figures } & & & & $0.191^{* * *}$ & $0.178^{* * *}$ & $0.171^{* *}$ \\
\hline & & & & $(0.039)$ & $(0.047)$ & $(0.058)$ \\
\hline \multirow[t]{2}{*}{ IQ numbers } & & & & $0.144^{* * *}$ & $0.131 * *$ & 0.115 \\
\hline & & & & $(0.040)$ & $(0.048)$ & $(0.059)$ \\
\hline \multirow[t]{2}{*}{ IQ words } & & & & 0.011 & 0.002 & 0.001 \\
\hline & & & & $(0.033)$ & $(0.039)$ & $(0.048)$ \\
\hline \multirow[t]{2}{*}{ Mathematics test } & & & & & $0.216^{* * *}$ & $0.224^{* * *}$ \\
\hline & & & & & $(0.051)$ & $(0.061)$ \\
\hline \multirow[t]{2}{*}{ Reading test } & & & & & & $-0.161^{*}$ \\
\hline & & & & & & $(0.067)$ \\
\hline $\begin{array}{l}\text { Controls ethnicity and } \\
\text { parental education }\end{array}$ & no & yes & yes & yes & yes & yes \\
\hline Pseudo R2 & 0.034 & 0.054 & 0.066 & 0.072 & 0.073 & 0.070 \\
\hline $\mathrm{N}$ & 3477 & 3296 & 3255 & 3134 & 2255 & 1524 \\
\hline
\end{tabular}

Note: $*$ significant at the .05 level. ${ }^{* *}=$ significant at the .01 level. ${ }^{* * *}=$ significant at the .001 level.

comparative (dis)advantage. Preference for a STEM occupation gradually increases with track level. Students with higher selfconfidence in arithmetic are more likely to have a preference for a STEM occupation, although the estimates become smaller once we control for math achievement.

\subsection{Study preferences for STEM}

Table 4 provides the results with respect to preferences for a STEM study field, using the STEM preference measure from the study counseling test. The indicator for preference for a STEM field of study in higher education is on a different scale, as it is standardized with a mean of 0 and a standard deviation of 1 . Therefore a direct comparison to Table 3 in terms of coefficients is not possible. The results indicate that a one standard deviation increase in Openness to Experience is associated with a 0.08-0.12 standard deviation increase in the STEM field of study preference scale. For Agreeableness, this association equals around -0.14. The estimate for Neuroticism means that students, depending on the model, show between 0.05 and 0.11 standard deviation less interest in a STEM field of study, when they are one standard deviation higher on the Neuroticism scale. The coefficient is comparable to that of Openness, in the most complete model. Conscientiousness has a significant negative association with preference for a STEM field of study at the .05 level in model 4, but the p-value becomes respectively .057 and .077 in models 5 and 6 . Extraversion has a significant association with STEM field of study preference in the reduced Models 1-4, but this is driven by differences in sex, study track and math achievement.

As mentioned before, the STEM study preference measure is only available for a subset of students. Hence, differences in results between Tables 3 and 4 can partly be caused by differences in the sample. When we estimate results for STEM occupational preferences with the limited sample, we obtain largely similar results. The estimates decrease somewhat for Openness to Experience and Conscientiousness and increase somewhat for Neuroticism. As such, the difference in results between Tables 3 and 4 for the latter two variables appear partly because of the sample.

Results for the other indicators are in the same direction as in Table 3. The main difference is the statistically insignificant result for the IQ numbers score. Confidence in arithmetic and reading achievement are statistically insignificant in the most complete model, but note that the sample size is particularly small in Model 6.

\subsection{STEM specialization choice}

The analyses presented so far focus on STEM preferences, either towards study programs or towards occupations. We now analyze 
Table 4

OLS estimates STEM study field preference (grade 9).

\begin{tabular}{|c|c|c|c|c|c|c|}
\hline & (1) & (2) & (3) & (4) & (5) & (6) \\
\hline Openness & $\begin{array}{c}0.198^{* * *} \\
(0.028)\end{array}$ & $\begin{array}{c}0.095^{* * *} \\
(0.025)\end{array}$ & $\begin{array}{c}0.090 * * * \\
(0.025)\end{array}$ & $\begin{array}{l}0.084 * * \\
(0.026)\end{array}$ & $\begin{array}{l}0.092 * * \\
(0.032)\end{array}$ & $\begin{array}{l}0.117^{* *} \\
(0.038)\end{array}$ \\
\hline Conscientiousness & $\begin{array}{c}-0.078^{* *} \\
(0.027)\end{array}$ & $\begin{array}{l}-0.034 \\
(0.023)\end{array}$ & $\begin{array}{c}-0.046^{*} \\
(0.024)\end{array}$ & $\begin{array}{c}-0.050^{*} \\
(0.025)\end{array}$ & $\begin{array}{l}-0.055 \\
(0.029)\end{array}$ & $\begin{array}{l}-0.062 \\
(0.035)\end{array}$ \\
\hline Extraversion & $\begin{array}{c}-0.122 * * * \\
(0.027)\end{array}$ & $\begin{array}{c}-0.079^{* *} \\
(0.024)\end{array}$ & $\begin{array}{c}-0.073^{* *} \\
(0.024)\end{array}$ & $\begin{array}{c}-0.059^{*} \\
(0.025)\end{array}$ & $\begin{array}{l}-0.018 \\
(0.029)\end{array}$ & $\begin{array}{l}-0.029 \\
(0.034)\end{array}$ \\
\hline Agreeableness & $\begin{array}{c}-0.280^{* * *} \\
(0.033)\end{array}$ & $\begin{array}{c}-0.116^{* * *} \\
(0.031)\end{array}$ & $\begin{array}{c}-0.117^{* * *} \\
(0.030)\end{array}$ & $\begin{array}{c}-0.127^{* * *} \\
(0.032)\end{array}$ & $\begin{array}{c}-0.148^{* * *} \\
(0.037)\end{array}$ & $\begin{array}{c}-0.141 * * \\
(0.045)\end{array}$ \\
\hline Neuroticism & $\begin{array}{c}-0.159^{* * *} \\
(0.027)\end{array}$ & $\begin{array}{c}-0.058^{*} \\
(0.024)\end{array}$ & $\begin{array}{c}-0.048^{*} \\
(0.025)\end{array}$ & $\begin{array}{c}-0.052^{*} \\
(0.025)\end{array}$ & $\begin{array}{c}-0.059^{*} \\
(0.030)\end{array}$ & $\begin{array}{c}-0.108^{* *} \\
(0.037)\end{array}$ \\
\hline Female & & $\begin{array}{c}-1.068^{* * *} \\
(0.049)\end{array}$ & $\begin{array}{c}-1.034^{* * *} \\
(0.050)\end{array}$ & $\begin{array}{c}-1.053^{* * *} \\
(0.051)\end{array}$ & $\begin{array}{c}-1.095^{* * *} \\
(0.059)\end{array}$ & $\begin{array}{c}-1.021 * * * \\
(0.074)\end{array}$ \\
\hline Atheneum & & $\begin{array}{c}0.096 \\
(0.050)\end{array}$ & $\begin{array}{c}0.079 \\
(0.050)\end{array}$ & $\begin{array}{c}0.038 \\
(0.052)\end{array}$ & $\begin{array}{l}-0.023 \\
(0.063)\end{array}$ & $\begin{array}{c}0.005 \\
(0.082)\end{array}$ \\
\hline Gymnasium & & $\begin{array}{c}0.062 \\
(0.068)\end{array}$ & $\begin{array}{c}0.044 \\
(0.068)\end{array}$ & $\begin{array}{l}-0.006 \\
(0.070)\end{array}$ & $\begin{array}{c}0.025 \\
(0.086)\end{array}$ & $\begin{array}{c}0.122 \\
(0.115)\end{array}$ \\
\hline Confidence in arithmetic & & & $\begin{array}{c}0.051 * * * \\
(0.013)\end{array}$ & $\begin{array}{l}0.037 * * \\
(0.013)\end{array}$ & $\begin{array}{c}0.031 * \\
(0.015)\end{array}$ & $\begin{array}{c}0.022 \\
(0.019)\end{array}$ \\
\hline IQ figures & & & & $\begin{array}{l}0.080 * * \\
(0.026)\end{array}$ & $\begin{array}{l}0.102^{* *} \\
(0.031)\end{array}$ & $\begin{array}{l}0.117^{* *} \\
(0.039)\end{array}$ \\
\hline IQ numbers & & & & $\begin{array}{c}0.016 \\
(0.026)\end{array}$ & $\begin{array}{c}0.023 \\
(0.031)\end{array}$ & $\begin{array}{c}0.009 \\
(0.039)\end{array}$ \\
\hline IQ words & & & & $\begin{array}{c}0.031 \\
(0.022)\end{array}$ & $\begin{array}{c}0.016 \\
(0.026)\end{array}$ & $\begin{array}{c}0.024 \\
(0.032)\end{array}$ \\
\hline Mathematics test & & & & & $\begin{array}{l}0.086^{*} \\
(0.035)\end{array}$ & $\begin{array}{l}0.123^{* *} \\
(0.042)\end{array}$ \\
\hline Reading test & & & & & & $\begin{array}{l}-0.045 \\
(0.047)\end{array}$ \\
\hline $\begin{array}{l}\text { Controls ethnicity and } \\
\text { parental education }\end{array}$ & no & yes & yes & yes & yes & yes \\
\hline Adjusted R2 & 0.132 & 0.374 & 0.383 & 0.394 & 0.415 & 0.406 \\
\hline $\mathrm{N}$ & 1350 & 1271 & 1254 & 1181 & 851 & 580 \\
\hline
\end{tabular}

Note: ${ }^{*}=$ significant at the .05 level. ${ }^{* *}=$ significant at the .01 level. ${ }^{* *}=$ significant at the .001 level.

the relation between personality and choosing the Science \& Technology subtrack in higher secondary education, which is the first specialization choice that students make in the Dutch education system. These results are presented in Table 5.

Table 5 reveals a strong and robust relation between Extraversion and STEM specialization. A 1 SD increase in Extraversion is associated with an increase in choosing the S\&T track of 22 to 25 percent, which is highly substantial. For Conscientiousness, there is no relation with S\&T choice in any of the models. The results for the other three Big Five factors are more ambiguous. Both Openness to Experience (positive) and Neuroticism (negative) show strong associations to STEM specialization in Model 1, but these are largely driven by sex and track. Estimates are statistically insignificant in the more complete models but point estimates are similar in Model 6 compared to Model 2. Therefore this result could be driven by the smaller sample sizes in the more extensive models. We will further investigate this in Section 7.1. For Agreeableness, Model 1 also shows a strong (negative) association with S\&T choice which is again largely driven by sex and track differences. The estimate for Agreeableness is statistically significant in all models but the final Model 6 , and shows a relatively strong sensitivity to including reading achievement. As the analysis in Section 7 will show, this sensitivity does not occur because of a confounding relation with reading scores, but because of the reduction in sample size.

Hence, it remains somewhat inconclusive whether Openness to Experience, Agreeableness and Neuroticism are predictive of STEM specialization once cognitive ability and background are controlled for. In any case, the statistical significance of these indicators is already lower in the reduced Model 2 compared to the results for preferences, and also substantially lower in size compared to Extraversion. Therefore, it appears that Big Five traits are a stronger determinant of STEM preference than for actual choices towards STEM specialization, with one very notable exception in terms of Extraversion. ${ }^{5}$ On the other hand, Table 5 shows strong associations between S\&T choice and all measures of IQ and math achievement, math self-confidence and being in the top track (and, as expected, an especially strong relation to sex). As such, these results suggest that actual choices towards STEM are driven relatively more by ability indicators than by personality. ${ }^{6}$ We now provide a more direct comparison of these components.

\footnotetext{
${ }^{5}$ Studies have shown that relations between personality traits and school outcomes may operate through motivation or work drive (see, e.g., Lounsbury, Sundstrom, Loveland, \& Gibson, 2003). We assessed this potential mediator by adding a school motivation variable to the model. This leads to virtually identical estimates, and motivation itself is not a statistically significant predictor of STEM outcomes in the full model. Hence, the relation between personality and STEM does not appear mediated by motivation.

${ }^{6}$ The finding that IQ relates strongly to all STEM outcomes, also conditional on math achievement, is an important finding, since many studies on STEM choice only consider math scores as measures of cognitive achievement.
} 
Table 5

Logit estimates STEM specialization choice (grade 9).

\begin{tabular}{|c|c|c|c|c|c|c|}
\hline & (1) & (2) & (3) & (4) & (5) & (6) \\
\hline \multirow[t]{2}{*}{ Openness } & $0.308^{* * *}$ & $0.151^{* *}$ & $0.133^{*}$ & 0.115 & 0.101 & 0.126 \\
\hline & $(0.053)$ & $(0.058)$ & $(0.059)$ & $(0.061)$ & $(0.072)$ & $(0.088)$ \\
\hline \multirow[t]{2}{*}{ Conscientiousness } & 0.008 & 0.068 & 0.029 & 0.042 & 0.048 & 0.061 \\
\hline & $(0.048)$ & $(0.051)$ & $(0.053)$ & $(0.054)$ & $(0.064)$ & $(0.079)$ \\
\hline \multirow[t]{2}{*}{ Extraversion } & $-0.357^{* * *}$ & $-0.306^{* * *}$ & $-0.301^{* * *}$ & $-0.280^{* * *}$ & $-0.249^{* * *}$ & $-0.284 * * *$ \\
\hline & $(0.050)$ & $(0.054)$ & $(0.055)$ & $(0.057)$ & $(0.067)$ & $(0.080)$ \\
\hline \multirow[t]{2}{*}{ Agreeableness } & $-0.317^{* * *}$ & $-0.137^{*}$ & $-0.126^{*}$ & $-0.157^{*}$ & $-0.182^{*}$ & -0.084 \\
\hline & $(0.056)$ & $(0.061)$ & $(0.063)$ & $(0.065)$ & $(0.077)$ & $(0.095)$ \\
\hline \multirow[t]{2}{*}{ Neuroticism } & $-0.282^{* * *}$ & -0.108 & -0.062 & -0.034 & -0.054 & -0.102 \\
\hline & $(0.051)$ & $(0.056)$ & $(0.057)$ & $(0.059)$ & $(0.070)$ & $(0.087)$ \\
\hline \multirow[t]{2}{*}{ Female } & & $-1.412^{* * *}$ & $-1.258^{* * *}$ & $-1.261^{* * *}$ & $-1.261^{* * *}$ & $-1.189 * * *$ \\
\hline & & $(0.119)$ & $(0.122)$ & $(0.124)$ & $(0.145)$ & $(0.181)$ \\
\hline \multirow[t]{2}{*}{ Atheneum } & & $0.422^{* * *}$ & $0.361 * *$ & 0.161 & -0.069 & 0.065 \\
\hline & & $(0.108)$ & $(0.110)$ & $(0.116)$ & $(0.142)$ & $(0.188)$ \\
\hline \multirow[t]{2}{*}{ Gymnasium } & & $0.651 * * *$ & $0.582^{* * *}$ & 0.311 & 0.251 & $0.606^{*}$ \\
\hline & & $(0.159)$ & $(0.163)$ & $(0.172)$ & $(0.206)$ & $(0.268)$ \\
\hline \multirow[t]{2}{*}{ Confidence in arithmetic } & & & $0.240 * * *$ & $0.200^{* * *}$ & $0.184 * * *$ & $0.202^{* * *}$ \\
\hline & & & $(0.033)$ & $(0.034)$ & $(0.040)$ & $(0.050)$ \\
\hline \multirow[t]{2}{*}{ IQ figures } & & & & $0.243^{* * *}$ & $0.233^{* *}$ & $0.282 * *$ \\
\hline & & & & $(0.060)$ & $(0.073)$ & $(0.091)$ \\
\hline \multirow[t]{2}{*}{ IQ numbers } & & & & $0.228 * * *$ & $0.213^{* *}$ & 0.164 \\
\hline & & & & $(0.066)$ & $(0.079)$ & $(0.098)$ \\
\hline \multirow[t]{2}{*}{ IQ words } & & & & 0.032 & 0.073 & 0.132 \\
\hline & & & & $(0.051)$ & $(0.060)$ & $(0.076)$ \\
\hline \multirow[t]{2}{*}{ Mathematics test } & & & & & $0.366^{* * *}$ & $0.373^{* * *}$ \\
\hline & & & & & $(0.080)$ & (0.097) \\
\hline \multirow[t]{2}{*}{ Reading test } & & & & & & -0.166 \\
\hline & & & & & & $(0.104)$ \\
\hline $\begin{array}{l}\text { Controls ethnicity and } \\
\text { parental education }\end{array}$ & no & yes & yes & yes & yes & yes \\
\hline PseudoR2 & 0.052 & 0.112 & 0.134 & 0.143 & 0.162 & 0.167 \\
\hline $\mathrm{N}$ & 3477 & 3296 & 3255 & 3134 & 2255 & 1524 \\
\hline
\end{tabular}

Note: ${ }^{*}=$ significant at the .05 level. $* *=$ significant at the .01 level. $* * *=$ significant at the .001 level.

\subsection{Comparing coefficients}

Fig. 2 shows results when the coefficients for Model 6 of Tables 3-5 are rescaled, thereby anchoring the coefficient for the IQ figures subscore at the value of 1 (underlying coefficients, also for Models 4 and 5, are shown in Table 3 of Web Appendix B). This allows for more directly comparing the coefficients between the different STEM outcomes, and for assessing the relative importance of cognitive skills versus personality traits in explaining STEM preferences and specialization choice.

Fig. 2 highlights several conclusions. First, the relation between Agreeableness and both of the STEM preference measures is especially strong, exceeding that of the IQ figures subscore, as well as all other measures of cognitive ability. The relation between Openness to Experience and STEM preferences is on par with that of the IQ figures subscore. Estimates for Extraversion exceed those of the IQ anchor for occupational STEM preferences, and also for STEM specialization. ${ }^{7}$ Hence, while Extraversion is the only statistically significant predictor of S\&T track choice, the magnitude of this association is sizable. Conscientiousness and Neuroticism show relations to preferences (occupational and study preferences, respectively), but with relatively low estimates, and neither relates significantly to STEM specialization. As mentioned before, the lack of statistically significant results with respect to STEM specialization for any other factor other than Extraversion could be due to small sample sizes in the more extensive models. Table 3 in Web Appendix B shows, however, that the point estimates are also markedly lower than for the preference outcomes, when we anchor results on the association of the figures subscore of IQ.

For all our main results (models 4-6) we have also corrected for multiple comparisons. Therefore, in Table 6, we show our estimates with Bonferroni corrected p-values, as well as the results of F-tests for joint significance of the personality traits. Table 6 shows very similar results as before. The main difference is that Conscientiousness is no longer significant in any model.

\subsection{Differences by sex}

The results from Tables 3-5 also emphasize the role of sex as the dominant factor in explaining STEM preferences and choice, also

\footnotetext{
7 This remains so when we exclude the IQ subscores for numbers and words. Hence, the IQ figures coefficient is not mitigated here by the inclusion of other IQ subscores.
} 
1.5

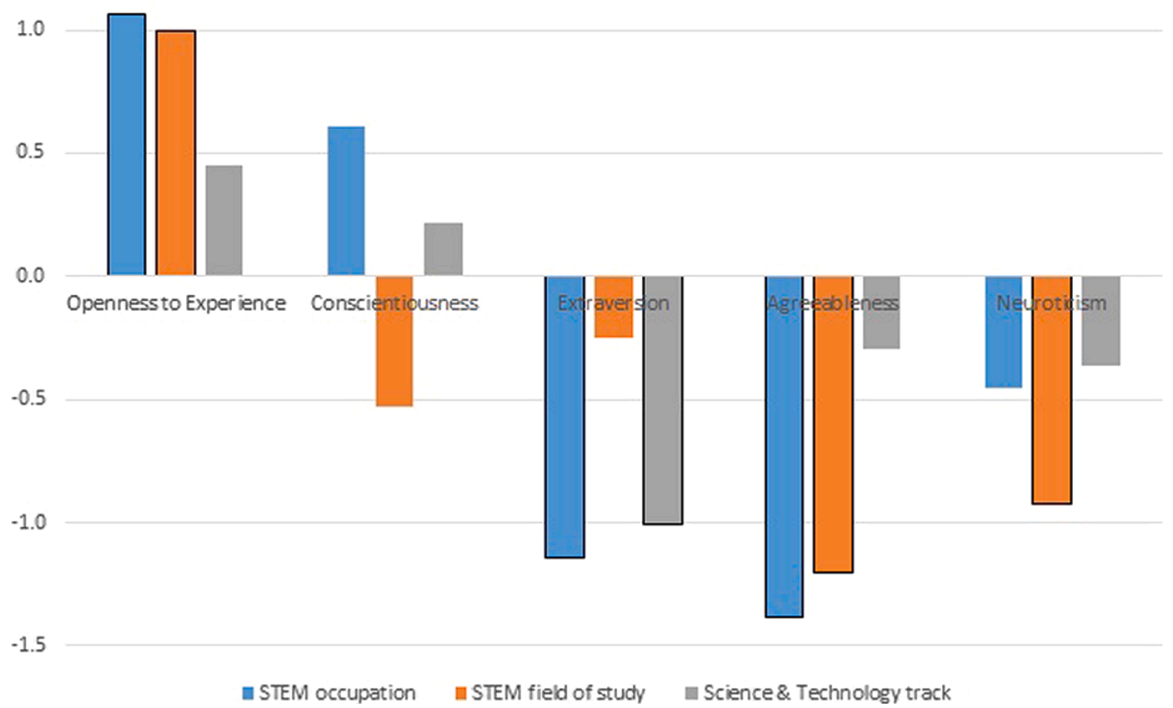

Fig. 2. Main results rescaled around IQ figures. Note: bars with solid borders are significant at the .01 level.

Table 6

Main results corrected for multiple comparisons.

\begin{tabular}{|c|c|c|c|c|c|c|c|c|c|}
\hline & \multicolumn{3}{|c|}{ Preference STEM occupation } & \multicolumn{3}{|c|}{ Preference STEM field of study } & \multicolumn{3}{|c|}{ S\&T track } \\
\hline & (4) & (5) & (6) & (4) & (5) & (6) & (4) & (5) & (6) \\
\hline \multicolumn{10}{|c|}{ Bonferroni adjusted p-values } \\
\hline Openness & $\begin{array}{c}0.192^{* * *} \\
{[0.000]}\end{array}$ & $\begin{array}{l}0.174^{* * *} \\
{[0.001]}\end{array}$ & $\begin{array}{l}0.182^{* *} \\
{[0.008]}\end{array}$ & $\begin{array}{l}0.084^{* * *} \\
{[0.007]}\end{array}$ & $\begin{array}{l}0.092^{*} \\
{[0.018]}\end{array}$ & $\begin{array}{l}0.117^{*} \\
{[0.011]}\end{array}$ & $\begin{array}{c}0.115 \\
{[0.288]}\end{array}$ & $\begin{array}{c}0.101 \\
{[0.796]}\end{array}$ & $\begin{array}{c}0.126 \\
{[0.761]}\end{array}$ \\
\hline Conscientiousness & $\begin{array}{c}0.069 \\
{[0.281]}\end{array}$ & $\begin{array}{c}0.068 \\
{[0.551]}\end{array}$ & $\begin{array}{c}0.104 \\
{[0.217]}\end{array}$ & $\begin{array}{l}-0.050 \\
{[0.214]}\end{array}$ & $\begin{array}{l}-0.055 \\
{[0.286]}\end{array}$ & $\begin{array}{l}-0.062 \\
{[0.383]}\end{array}$ & $\begin{array}{c}0.042 \\
{[1.000]}\end{array}$ & $\begin{array}{c}0.048 \\
{[1.000]}\end{array}$ & $\begin{array}{c}0.061 \\
{[1.000]}\end{array}$ \\
\hline Extraversion & $\begin{array}{c}-0.290^{* * *} \\
{[0.000]}\end{array}$ & $\begin{array}{c}-0.256^{* * *} \\
{[0.000]}\end{array}$ & $\begin{array}{c}-0.196^{* * *} \\
{[0.001]}\end{array}$ & $\begin{array}{l}-0.059 \\
{[0.093]}\end{array}$ & $\begin{array}{l}-0.018 \\
{[1.000]}\end{array}$ & $\begin{array}{l}-0.029 \\
{[1.000]}\end{array}$ & $\begin{array}{c}-0.280^{* * * *} \\
{[0.000]}\end{array}$ & $\begin{array}{c}-0.249^{* *} \\
{[0.001]}\end{array}$ & $\begin{array}{c}-0.284^{* *} \\
{[0.002]}\end{array}$ \\
\hline Agreeableness & $\begin{array}{c}-0.230 * * * \\
{[0.000]}\end{array}$ & $\begin{array}{c}-0.239 * * * \\
{[0.000]}\end{array}$ & $\begin{array}{c}-0.237^{* *} \\
{[0.001]}\end{array}$ & $\begin{array}{c}-0.127^{* * *} \\
{[0.000]}\end{array}$ & $\begin{array}{c}-0.148^{* * *} \\
{[0.000]}\end{array}$ & $\begin{array}{c}-0.141^{* *} \\
{[0.009]}\end{array}$ & $\begin{array}{l}-0.157 \\
{[0.073]}\end{array}$ & $\begin{array}{l}-0.182 \\
{[0.093]}\end{array}$ & $\begin{array}{l}-0.084 \\
{[1.000]}\end{array}$ \\
\hline Neuroticism & $\begin{array}{l}-0.059 \\
{[0.631]}\end{array}$ & $\begin{array}{c}-0.071 \\
{[0.591]}\end{array}$ & $\begin{array}{l}-0.078 \\
{[0.819]}\end{array}$ & $\begin{array}{l}-0.052 \\
{[0.203]}\end{array}$ & $\begin{array}{l}-0.059 \\
{[0.236]}\end{array}$ & $\begin{array}{c}-0.108^{*} \\
{[0.017]}\end{array}$ & $\begin{array}{l}-0.034 \\
{[1.000]}\end{array}$ & $\begin{array}{l}-0.054 \\
{[1.000]}\end{array}$ & $\begin{array}{l}-0.102 \\
{[1.000]}\end{array}$ \\
\hline \multicolumn{10}{|c|}{ Joint significance (F-test) } \\
\hline Chi-squared & 122.59 & 79.44 & 44.56 & 8.60 & 6.77 & 6.52 & 40.99 & 27.77 & 18.53 \\
\hline Prob $>$ Chi2 & 0.0000 & 0.0000 & 0.0000 & 0.0000 & 0.0000 & 0.0000 & 0.0000 & 0.0000 & 0.0024 \\
\hline
\end{tabular}

Note: ${ }^{*}=$ significant at the .05 level. ${ }^{* *}=$ significant at the .01 level. ${ }^{* * *}=$ significant at the .001 level.

conditional on cognitive skills and personality traits of students. This association is largest with respect to field of study preferences. Hence, female students appear to have an especially negative view of STEM study fields, compared to working in a STEM job in the future. In light of the difference in educational preferences, one could even consider the very sizable difference in actual choices to be comparatively modest. This also suggests that, in order to get more women into STEM fields, gains can especially be made in changing preferences for STEM study fields among girls.

Since sex is a big driver of differences in STEM preferences and choices, we also perform split sample analyses by sex for all main outcomes. The results are shown in Web Appendix B. For occupational preferences, there are three notable differences. Firstly, the positive relation between Conscientiousness and preference for a STEM occupation is only apparent for girls. Secondly, while for both boys and girls Agreeableness is negatively associated with preference for a STEM occupation, the coefficient is around three times larger for girls. Thirdly, the negative association between Neuroticism and preference for a STEM occupation in models 1-3 is only found for girls, and is also statistically significant for girls in models 4 and 5 .

For STEM field of study preferences, the separate analyses reveal that there is a weak negative relation between Conscientiousness and preference for a STEM field of study, but only for boys, and only in models 4 and 5 these estimates are significant at the .05 level. Furthermore, while there was no statistically significant relation between Extraversion and preference for a STEM field of study for the sample as a whole, we do identify strong negative estimates for girls. The negative relationship between Neuroticism and preference for a STEM field of study is only found for boys. 
Table 7

Correcting for reduced sample size (SEM and FIML with sample from Model 4).

\begin{tabular}{|c|c|c|c|c|c|c|c|c|c|}
\hline & \multicolumn{3}{|c|}{ Preference STEM occupation } & \multicolumn{3}{|c|}{ Preference STEM field of study } & \multicolumn{3}{|c|}{ S\&T track } \\
\hline & (4) & (5) & (6) & (4) & (5) & (6) & (4) & (5) & (6) \\
\hline \multirow[t]{2}{*}{ Openness } & $0.194 * * *$ & $0.183^{* * *}$ & $0.195^{* * *}$ & $0.084 * *$ & $0.078^{* *}$ & $0.084 * *$ & 0.116 & 0.100 & 0.114 \\
\hline & $(0.041)$ & $(0.041)$ & $(0.041)$ & $(0.026)$ & $(0.026)$ & $(0.026)$ & $(0.061)$ & $(0.062)$ & $(0.062)$ \\
\hline \multirow[t]{2}{*}{ Conscientiousness } & 0.069 & 0.067 & 0.069 & $-0.050^{*}$ & $-0.052^{*}$ & $-0.050^{*}$ & 0.042 & 0.034 & 0.035 \\
\hline & $(0.036)$ & $(0.036)$ & $(0.036)$ & $(0.025)$ & $(0.025)$ & $(0.024)$ & $(0.054)$ & $(0.055)$ & $(0.055)$ \\
\hline \multirow[t]{2}{*}{ Extraversion } & $-0.291 * * *$ & $-0.281^{* * *}$ & $-0.286^{* * *}$ & $-0.059^{*}$ & $-0.053^{*}$ & $-0.059^{*}$ & $-0.281^{* * *}$ & $-0.260 * * *$ & $-0.267^{* * *}$ \\
\hline & $(0.038)$ & $(0.038)$ & $(0.038)$ & $(0.025)$ & $(0.025)$ & $(0.025)$ & $(0.057)$ & $(0.057)$ & $(0.058)$ \\
\hline \multirow[t]{2}{*}{ Agreeableness } & $-0.233^{* * *}$ & $-0.245^{* * *}$ & $-0.236^{* * *}$ & $-0.127^{* * *}$ & $-0.129^{* * *}$ & $-0.123^{* * *}$ & $-0.159^{*}$ & $-0.181^{* *}$ & $-0.173^{* *}$ \\
\hline & $(0.046)$ & $(0.046)$ & $(0.046)$ & $(0.031)$ & $(0.031)$ & $(0.031)$ & $(0.065)$ & $(0.066)$ & $(0.067)$ \\
\hline \multirow[t]{2}{*}{ Neuroticism } & -0.059 & -0.060 & -0.062 & $-0.052^{*}$ & $-0.052^{*}$ & $-0.050^{*}$ & -0.034 & -0.036 & -0.040 \\
\hline & $(0.039)$ & $(0.039)$ & $(0.039)$ & $(0.025)$ & $(0.025)$ & $(0.025)$ & $(0.059)$ & $(0.060)$ & $(0.060)$ \\
\hline \multirow[t]{2}{*}{ Female } & $-0.807^{* * *}$ & $-0.800 * * *$ & $-0.769 * * *$ & $-1.053^{* * *}$ & $-1.055^{* * *}$ & $-1.041^{* * *}$ & $-1.261^{* * *}$ & $-1.250 * * *$ & $-1.220^{* * * *}$ \\
\hline & $(0.076)$ & $(0.077)$ & $(0.077)$ & $(0.051)$ & $(0.051)$ & $(0.051)$ & $(0.124)$ & (0.125) & $(0.126)$ \\
\hline \multirow[t]{2}{*}{ Atheneum } & 0.133 & 0.035 & 0.122 & 0.038 & -0.010 & 0.027 & 0.161 & -0.014 & 0.061 \\
\hline & $(0.076)$ & $(0.080)$ & $(0.085)$ & $(0.052)$ & $(0.055)$ & $(0.058)$ & $(0.116)$ & $(0.123)$ & $(0.131)$ \\
\hline \multirow[t]{2}{*}{ Gymnasium } & 0.173 & 0.040 & 0.194 & -0.006 & -0.064 & 0.002 & 0.311 & 0.077 & 0.206 \\
\hline & $(0.119)$ & $(0.124)$ & $(0.133)$ & $(0.070)$ & $(0.073)$ & $(0.081)$ & $(0.172)$ & $(0.181)$ & $(0.196)$ \\
\hline \multirow[t]{2}{*}{ Confidence in arithmetic } & $0.185^{* * *}$ & $0.177^{* * *}$ & $0.175^{* * * *}$ & $0.037^{* * *}$ & $0.035^{* *}$ & $0.034 * *$ & $0.200^{* * * *}$ & $0.186^{* * * *}$ & $0.184^{* * *}$ \\
\hline & $(0.021)$ & $(0.021)$ & $(0.021)$ & $(0.013)$ & $(0.013)$ & $(0.013)$ & $(0.034)$ & $(0.034)$ & $(0.034)$ \\
\hline \multirow[t]{2}{*}{ IQ figures } & $0.191^{* * *}$ & $0.168^{* * * *}$ & $0.183^{* * * *}$ & $0.080 * *$ & $0.070^{* *}$ & $0.076^{* *}$ & $0.243^{* * *}$ & $0.204 * *$ & $0.215^{* *}$ \\
\hline & $(0.039)$ & $(0.039)$ & $(0.040)$ & $(0.026)$ & $(0.026)$ & $(0.026)$ & $(0.060)$ & $(0.061)$ & $(0.062)$ \\
\hline \multirow[t]{2}{*}{ IQ numbers } & $0.144^{* * *}$ & $0.116^{* * *}$ & $0.120^{* *}$ & 0.016 & 0.005 & 0.008 & $0.228^{* * *}$ & $0.180^{* *}$ & $0.182^{* *}$ \\
\hline & $(0.040)$ & $(0.041)$ & $(0.041)$ & $(0.026)$ & $(0.026)$ & $(0.026)$ & $(0.066)$ & $(0.067)$ & $(0.067)$ \\
\hline \multirow[t]{2}{*}{ IQ words } & 0.011 & 0.011 & 0.014 & 0.031 & 0.029 & 0.030 & 0.032 & 0.030 & 0.034 \\
\hline & $(0.033)$ & $(0.033)$ & $(0.033)$ & $(0.022)$ & $(0.022)$ & $(0.022)$ & $(0.051)$ & $(0.051)$ & $(0.051)$ \\
\hline \multirow[t]{2}{*}{ Mathematics test } & & $0.204 * * *$ & $0.235^{* * *}$ & & $0.088^{*}$ & $0.090^{*}$ & & $0.364 * * *$ & $0.392^{* * *}$ \\
\hline & & $(0.050)$ & $(0.051)$ & & $(0.035)$ & $(0.035)$ & & $(0.079)$ & $(0.081)$ \\
\hline \multirow[t]{2}{*}{ Reading test } & & & $-0.179^{* *}$ & & & -0.073 & & & -0.152 \\
\hline & & & $(0.057)$ & & & $(0.039)$ & & & $(0.089)$ \\
\hline $\mathrm{N}$ & 3134 & 3134 & 3134 & 1181 & 1181 & 1181 & 3134 & 3134 & 3134 \\
\hline
\end{tabular}

Note: $*=$ significant at the .05 level. ${ }^{* *}=$ significant at the .01 level. ${ }^{* * *}=$ significant at the .001 level. 
Finally, the sex-specific analyses for STEM specialization show especially strong differences by sex. The strong relation for Extraversion identified for the full sample appears largely exclusive to boys. For girls, on the other hand, there is a highly statistically significant relation with Openness to Experience, while the relation with Agreeableness (negative) is only significant in models 4 and 5. To sum up, girls who choose a STEM specialization are characterized by high Openness to Experience and low Agreeableness, while boys in this specialization are mainly less extravert than boys that select other specializations.

The results for STEM specialization remained somewhat inconclusive with respect to Agreeableness and, to a lesser extent, Openness to Experience, for which the estimates were on the margin of statistical significance and also depending on the model specification. The results from this subsection show that this ambiguity disappears in the separate analysis by sex, and that these indicators are predictive for girls but not for boys. The tables further show that the results for the overall sample are a much closer reflection of the results for boys than of the results for girl. This is a natural consequence of the fact that far fewer girls select the S\&T subtrack. Additionally, these results document that personality is a stronger predictor of STEM specialization for girls than for boys (this is a similar result as obtained by Cobb-Clark \& Tan (2011) with respect to occupational choice for Science and Technology). This could also be a direct consequence of the low share of girls in this subtrack, and therefore the few girls that do choose this specialization are characterized by a very specific personality set.

\section{Robustness checks}

\subsection{Sample size}

The decreasing sample size once we move from Model 4 to Model 5 and Model 6 are potentially problematic. Because we want to establish whether differences between models and between our different STEM indicators are not merely caused by the reduced sample size, and consequently, reduced power, we estimate a Structural Equation Model with Full Information Maximum Likelihood (FIML), set on the sample from model 4, i.e. the sample with non-missings for the Big Five variables, all control variables, confidence in arithmetic and the three IQ variables. As in Section 6, the analysis of STEM occupation is estimated with an ordered logit model, the analysis of STEM field of study with a linear regression model, and the analysis of the S\&T track with a logit model. The results are

Table 8

Correcting for measurement error in personality (SEM and FIML with sample from Model 4).

\begin{tabular}{|c|c|c|c|c|c|c|c|c|c|}
\hline & \multicolumn{3}{|c|}{ Preference STEM occupation } & \multicolumn{3}{|c|}{ Preference STEM field of study } & \multicolumn{3}{|c|}{ S\&T track } \\
\hline & (4) & (5) & (6) & (4) & (5) & (6) & (4) & (5) & (6) \\
\hline Openness & $\begin{array}{c}0.222^{* * *} \\
(0.057)\end{array}$ & $\begin{array}{c}0.212^{* * *} \\
(0.056)\end{array}$ & $\begin{array}{c}0.245 * * * \\
(0.061)\end{array}$ & $\begin{array}{l}0.099 * * \\
(0.034)\end{array}$ & $\begin{array}{l}0.092^{* *} \\
(0.034)\end{array}$ & $\begin{array}{l}0.099 * * \\
(0.035)\end{array}$ & $\begin{array}{c}0.111 \\
(0.083)\end{array}$ & $\begin{array}{c}0.108 \\
(0.084)\end{array}$ & $\begin{array}{c}0.162 \\
(0.092)\end{array}$ \\
\hline Conscientiousness & $\begin{array}{c}0.043 \\
(0.058)\end{array}$ & $\begin{array}{c}0.035 \\
(0.056)\end{array}$ & $\begin{array}{c}0.038 \\
(0.065)\end{array}$ & $\begin{array}{l}-0.064 \\
(0.036)\end{array}$ & $\begin{array}{l}-0.064 \\
(0.035)\end{array}$ & $\begin{array}{l}-0.063 \\
(0.035)\end{array}$ & $\begin{array}{l}-0.064 \\
(0.085)\end{array}$ & $\begin{array}{l}-0.015 \\
(0.084)\end{array}$ & $\begin{array}{c}0.032 \\
(0.098)\end{array}$ \\
\hline Extraversion & $\begin{array}{c}-0.388^{* * * *} \\
(0.073)\end{array}$ & $\begin{array}{c}-0.399 * * * \\
(0.071)\end{array}$ & $\begin{array}{c}-0.384 * * * \\
(0.077)\end{array}$ & $\begin{array}{l}-0.071 \\
(0.039)\end{array}$ & $\begin{array}{l}-0.062 \\
(0.039)\end{array}$ & $\begin{array}{l}-0.069 \\
(0.039)\end{array}$ & $\begin{array}{c}-0.465^{* * *} \\
(0.111)\end{array}$ & $\begin{array}{c}-0.375^{* * *} \\
(0.106)\end{array}$ & $\begin{array}{c}-0.349 * * \\
(0.115)\end{array}$ \\
\hline Agreeableness & $\begin{array}{c}-0.194 * \\
(0.085)\end{array}$ & $\begin{array}{c}-0.178^{*} \\
(0.080)\end{array}$ & $\begin{array}{c}-0.210^{*} \\
(0.092)\end{array}$ & $\begin{array}{c}-0.118^{* *} \\
(0.044)\end{array}$ & $\begin{array}{c}-0.121^{* *} \\
(0.044)\end{array}$ & $\begin{array}{c}-0.116^{* *} \\
(0.044)\end{array}$ & $\begin{array}{l}-0.003 \\
(0.122)\end{array}$ & $\begin{array}{l}-0.113 \\
(0.116)\end{array}$ & $\begin{array}{l}-0.151 \\
(0.134)\end{array}$ \\
\hline Neuroticism & $\begin{array}{l}-0.072 \\
(0.053)\end{array}$ & $\begin{array}{l}-0.110^{*} \\
(0.051)\end{array}$ & $\begin{array}{l}-0.121 * \\
(0.055)\end{array}$ & $\begin{array}{l}-0.067 * \\
(0.030)\end{array}$ & $\begin{array}{l}-0.066^{*} \\
(0.030)\end{array}$ & $\begin{array}{l}-0.064^{*} \\
(0.030)\end{array}$ & $\begin{array}{c}-0.112 \\
(0.080)\end{array}$ & $\begin{array}{l}-0.112 \\
(0.078)\end{array}$ & $\begin{array}{c}-0.083 \\
(0.083)\end{array}$ \\
\hline Female & $\begin{array}{c}-0.716^{* * * *} \\
(0.085)\end{array}$ & $\begin{array}{c}-0.712^{* * *} \\
(0.084)\end{array}$ & $\begin{array}{c}-0.651^{* * *} \\
(0.086)\end{array}$ & $\begin{array}{c}-1.004^{* * *} \\
(0.055)\end{array}$ & $\begin{array}{c}-1.006^{* * *} \\
(0.055)\end{array}$ & $\begin{array}{c}-0.993^{* * *} \\
(0.056)\end{array}$ & $\begin{array}{c}-1.182^{* * *} \\
(0.135)\end{array}$ & $\begin{array}{c}-1.154^{* * *} \\
(0.134)\end{array}$ & $\begin{array}{c}-1.127^{* * *} \\
(0.138)\end{array}$ \\
\hline Atheneum & $\begin{array}{c}0.120 \\
(0.077)\end{array}$ & $\begin{array}{c}0.034 \\
(0.077)\end{array}$ & $\begin{array}{c}0.139 \\
(0.086)\end{array}$ & $\begin{array}{c}0.033 \\
(0.052)\end{array}$ & $\begin{array}{c}-0.012 \\
(0.055)\end{array}$ & $\begin{array}{c}0.025 \\
(0.058)\end{array}$ & $\begin{array}{c}0.146 \\
(0.118)\end{array}$ & $\begin{array}{c}-0.001 \\
(0.124)\end{array}$ & $\begin{array}{c}0.083 \\
(0.124)\end{array}$ \\
\hline Gymnasium & $\begin{array}{c}0.123 \\
(0.123)\end{array}$ & $\begin{array}{c}-0.003 \\
(0.127)\end{array}$ & $\begin{array}{c}0.167 \\
(0.136)\end{array}$ & $\begin{array}{c}-0.030 \\
(0.072)\end{array}$ & $\begin{array}{c}-0.083 \\
(0.075)\end{array}$ & $\begin{array}{c}-0.018 \\
(0.082)\end{array}$ & $\begin{array}{c}0.274 \\
(0.178)\end{array}$ & $\begin{array}{c}0.068 \\
(0.184)\end{array}$ & $\begin{array}{c}0.194 \\
(0.199)\end{array}$ \\
\hline Confidence in arithmetic & $\begin{array}{c}0.183^{* * *} \\
(0.021)\end{array}$ & $\begin{array}{c}0.172^{* * *} \\
(0.022)\end{array}$ & $\begin{array}{c}0.170 * * * \\
(0.022)\end{array}$ & $\begin{array}{l}0.038^{* *} \\
(0.013)\end{array}$ & $\begin{array}{l}0.036^{* *} \\
(0.013)\end{array}$ & $\begin{array}{l}0.035 * * \\
(0.013)\end{array}$ & $\begin{array}{c}0.202^{* * *} \\
(0.035)\end{array}$ & $\begin{array}{c}0.185^{* * *} \\
(0.035)\end{array}$ & $\begin{array}{c}0.180^{* * *} \\
(0.035)\end{array}$ \\
\hline IQ figures & $\begin{array}{c}0.191^{* * *} \\
(0.040)\end{array}$ & $\begin{array}{c}0.157^{* * *} \\
(0.040)\end{array}$ & $\begin{array}{c}0.183^{* * *} \\
(0.041)\end{array}$ & $\begin{array}{l}0.081^{* * *} \\
(0.026)\end{array}$ & $\begin{array}{l}0.072 * * \\
(0.026)\end{array}$ & $\begin{array}{l}0.079 * * \\
(0.026)\end{array}$ & $\begin{array}{c}0.238 * * * \\
(0.061)\end{array}$ & $\begin{array}{l}0.194 * * \\
(0.062)\end{array}$ & $\begin{array}{l}0.213^{* *} \\
(0.063)\end{array}$ \\
\hline IQ numbers & $\begin{array}{c}0.147^{* * *} \\
(0.041)\end{array}$ & $\begin{array}{l}0.117 * * \\
(0.042)\end{array}$ & $\begin{array}{l}0.126^{* *} \\
(0.042)\end{array}$ & $\begin{array}{c}0.014 \\
(0.026)\end{array}$ & $\begin{array}{c}0.003 \\
(0.027)\end{array}$ & $\begin{array}{c}0.007 \\
(0.027)\end{array}$ & $\begin{array}{l}0.220 * * \\
(0.067)\end{array}$ & $\begin{array}{l}0.177^{* *} \\
(0.068)\end{array}$ & $\begin{array}{l}0.189 * * \\
(0.068)\end{array}$ \\
\hline IQ words & $\begin{array}{c}0.007 \\
(0.034)\end{array}$ & $\begin{array}{c}0.010 \\
(0.034)\end{array}$ & $\begin{array}{c}0.006 \\
(0.034)\end{array}$ & $\begin{array}{c}0.026 \\
(0.022)\end{array}$ & $\begin{array}{c}0.025 \\
(0.022)\end{array}$ & $\begin{array}{c}0.025 \\
(0.022)\end{array}$ & $\begin{array}{c}0.027 \\
(0.052)\end{array}$ & $\begin{array}{c}0.029 \\
(0.052)\end{array}$ & $\begin{array}{c}0.029 \\
(0.052)\end{array}$ \\
\hline Mathematics test & & $\begin{array}{c}0.196^{* * *} \\
(0.051)\end{array}$ & $\begin{array}{c}0.202^{* * *} \\
(0.051)\end{array}$ & & $\begin{array}{l}0.086 * \\
(0.036)\end{array}$ & $\begin{array}{l}0.087 * \\
(0.036)\end{array}$ & & $\begin{array}{c}0.349 * * * \\
(0.079)\end{array}$ & $\begin{array}{c}0.364^{* * *} \\
(0.080)\end{array}$ \\
\hline Reading test & & & $\begin{array}{c}-0.193^{* *} \\
(0.058)\end{array}$ & & & $\begin{array}{l}-0.075 \\
(0.039)\end{array}$ & & & $\begin{array}{l}-0.166 \\
(0.089)\end{array}$ \\
\hline RMSEA & 0.067 & 0.066 & 0.065 & 0.057 & 0.056 & 0.055 & 0.066 & 0.065 & 0.065 \\
\hline CFI & 0.782 & 0.783 & 0.785 & 0.783 & 0.783 & 0.782 & 0.782 & 0.783 & 0.785 \\
\hline WRMR/SRMR & 3.012 & 2.945 & 2.822 & 0.055 & 0.054 & 0.054 & 2.934 & 2.871 & 2.822 \\
\hline Chi_SQ & 6669.68 & 6724.16 & 6858.50 & 2206.46 & 2226.74 & 2257.46 & 6669.05 & 6751.00 & 6858.50 \\
\hline $\mathrm{N}$ & 3134 & 3134 & 3134 & 1181 & 1181 & 1181 & 3134 & 3134 & 3134 \\
\hline
\end{tabular}

Note: ${ }^{*}=$ significant at the .05 level. ${ }^{* *}=$ significant at the .01 level. ${ }^{* * *}=$ significant at the .001 level. All models include the full set of controls. WRMR is reported for the first and third outcome, and the SRMR for the second outcome. 
shown in Table 7.

For preferences for a STEM occupation, we find few differences compared to Table 3. When using the full sample, the main differences are that the estimate for Extraversion is larger in Model 6 (-0.286 compared to -0.196), while the estimate for Conscientiousness is smaller in Model 6 (0.069 compared to 0.104$)$, and is no longer significant at the $5 \%$ level here, just like in the other models.

For preferences for a STEM field of study, the main difference compared to Table 4 is that Extraversion is now also negatively related to preferences for a STEM field of study in Models 5 and 6 . The indicators with statistically significant estimates in Table 4 all remain significant, but decrease somewhat in size. This holds in particular for Neuroticism, of which the estimate in Model 6 reduces by more than half.

Finally, for choosing the S\&T track, we find important differences with the original results from Table 5. Agreeableness is now significantly negatively related to choosing the S\&T track. The estimate of Agreeableness in Model 6 doubles in size. All in all, we find that the reduced sample size in models 5 and 6 has driven some of the estimated relations statistically insignificant, largely because of increases in standard errors and in some cases because of different point estimates as well. The most important conclusions are that Extraversion is now predictive across outcomes and that Agreeableness also is a significant predictor of STEM specialization choice.

\subsection{Measurement error}

Measurement error is a central issue for measures of personality. Personality traits are especially susceptible to measurement error, as they rely on self-reported measures for a relatively small set of items. This is especially relevant in our sample, as we rely on 4 or 5 items per construct. In this subsection, we therefore analyze to what extent measurement error in personality measures may bias our results.

To determine to what extent measurement error in the Big Five indicators affects our estimates from Section 6, we estimate a Structural Equation Model in which the factors of the Big Five are predicted by their individual items. For brevity, we only show models 4 to 6 from the previous tables. We estimate the Structural Equation Model again with FIML, so that we simultaneously correct for measurement error and for sample size differences. Hence, in order to assess the impact of measurement error, we should compare to Table 7. As previously, the analysis of STEM occupation is estimated with an ordered logit model, the analysis of STEM field of study with a linear regression model, and the analysis of the S\&T track with a logit model. Estimates are shown in Table 8, as well as measures of SEM model fit. The measures of factorial validity of the Big Five constructs (jointly) equal 0.083 and 0.082 for the RMSEA and 0.770 and 0.771 for the CFI, in the full sample and in the sample with STEM field of study preference measures, respectively.

Correcting for measurement error leads to some changes compared to both the original results in Tables $3-5$ and to Table 7 . The corrections mainly increase the estimates for Extraversion. The already sizable estimates increase with approximately $25 \%$ for all three STEM indicators. The estimates for Neuroticism with relation to preference for a STEM occupation become markedly larger and are now also significant. The estimates for Openness to Experience also slightly increase in some outcomes and specifications, most importantly in Model 6 in the STEM specialization choice analysis. Estimates for Agreeableness tend to become smaller across the different outcomes and specifications. For STEM specialization, the estimates turn insignificant in all models (4-6). Note that measurement error corrections may reduce estimates as well, because they also mitigate effects that occur from associations between the different constructs (e.g. noise in the Extraversion measure may lead Agreeableness to take up part of its effect in the regression model). Thus, it appears that any increasing effect from reducing measurement error in Agreeableness is trumped by reducing measurement error in other personality constructs as well.

Test scores are susceptible to measurement error as well. While this is partly mitigated in our context by having a range of tests available, it is still possible that attenuation bias in the cognitive measures by association leads to bias in the personality traits as well. We therefore estimate an extended SEM model that also uses the test items to construct factors for IQ, math and reading scores. Estimates are portrayed in Web Appendix C. Results are qualitatively similar for the personality traits. Additionally, they emphasize the dominance of the "IQ Figures" score, which increases in predictive power when corrected for measurement error, while the other IQ scores are now statistically insignificant.

FInally, we note that the fit measures of our model are relatively low. This is a common issue for studies that run confirmatory factor analysis on the Big Five Factor structure, see, e.g., McCrae, Zonderman, Costa, Bond, and Paunonen (1996, 1997). Some scholars therefore advocate exploratory factor analysis as an alternative. We rely on CFA in our main approach, as the IPIP items are designed on the basis of the Big Five factor structure, but provide results for an equivalent ESEM model in Web Appendix D for robustness. Estimates are qualitatively very similar, while the measures of SEM model fit are substantially better. ${ }^{8}$

\subsection{Earlier measures of personality}

In the previous analyses, we have used indicators of the Big Five that are measured at the same time as the dependent variables, i.e. in grade 9. As such, results are potentially susceptible to reverse causality. Having a preference for STEM could lead students to be more open to new experiences or to be less extravert, because they consequently partake in different activities, hang out with different peers etc. To address this issue, we can use data from the same students measured in grade 6 . In this way, the potential for reverse causality is

${ }^{8}$ Factorial validity improves as well, to 0.060 and 0.058 for the RMSEA and 0.920 and 0.926 for the CFI. 
reduced. Because we rely on grade 6 data, the overall sample size is considerably smaller, as only the Southern part of the region participates in the primary school data collection. The results are shown in Table 9.

Using the grade 6 indicators of the Big Five, our estimates are similar to the estimates of the main analyses, with some differences though. The results again largely indicate a positive relationship between Openness to Experience, and a negative relationship between Extraversion, Agreeableness and Neuroticism with the STEM outcome variables. Because of the relatively small sample size (especially for study preferences), the estimates lack precision, leading to lower statistical significance compared to results for the grade 9 personality measures. On the other hand, contrary to the main results, the estimates for Openness to Experience are now significant in all models for STEM specialization. On average, point estimates tend to be somewhat smaller though. There could be several explanations: it could hint at some degree of reverse causality, or can be an indication that either study preferences or personality traits (or both) have not stabilized yet at the age of 12 . Still, results are qualitatively similar as before, again pointing at comparatively large effect sizes for Openness and Agreeableness towards STEM preferences, and of Extraversion towards STEM choice.

\section{Conclusion}

In this paper, we investigate the role of personality traits in explaining students' educational and occupational preference for STEM, and their choice for STEM specialization in upper secondary school. Using a sample of students from a Dutch province, we find that personality traits are related to both preferences towards STEM and to STEM specialization choices. The size of these associations often rivals that of mathematics achievement and IQ. In general, the factors of the Big Five have a stronger association with preferences than with the actual choice. Extraversion is the strongest predictor of actual choice (effect size of 23-25 percent), while Openness to Experience and Agreeableness are the strongest predictors of preferences for a STEM field of study and occupation (effect sizes of around 0.10-0.15 of a standard deviation). Thus, higher Openness to Experience, lower Extraversion, lower Neuroticism, and lower Agreeableness are related to stronger preferences and specialization towards STEM. Conscientiousness, while typically being shown as the most significant of the Big Five when it comes to educational success, has little relation to STEM preference and specialization choice.

Additional analyses show that these results are largely robust to corrections for measurement error in personality traits or in achievement measures, and also largely hold when using earlier measures of personality. Additionally, heterogeneity analysis reveals different patterns for boys compared to girls, especially with respect to the STEM specialization choice. We identify a strong positive relation between choosing the STEM track and Openness to Experience for girls, while the negative relation between STEM specialization and Extraversion is especially strong for boys.

We argued in the introduction that, within the traditional economic model about study choice, personality traits are relevant because they can determine preferences and will be related to expected returns. It remains difficult to disentangle these two factors, because expressed preferences are partly shaped by expected returns. However, if expected returns are the main channel, we would have expected comparatively higher coefficients when STEM choice is the outcome compared to when STEM preferences are the outcome. We rather identify an opposite dynamic, suggesting that the link between personality and the return to STEM is not the main factor here. Relative effect sizes rather suggest that expected returns are a more important mechanism for the relation between STEM choice and cognitive skills.

The question remains how these findings can be used by policy makers to increase the inflow in STEM higher education, and consequently STEM occupations. There are two main ways in which one can interpret these findings. On the one hand, students with high Openness to Experience, low Extraversion and low Agreeableness can be targeted to increase STEM study choice, as these are the students where the STEM preference is high. Empirical evidence provided by Cunha, Heckman, and Schennach (2010) indicates that personality is more malleable than intelligence at younger ages. This could imply that interventions aimed at, e.g., increasing Openness to Experience can be beneficial for STEM enrollment. Alternatively, it can be argued that STEM studies and occupations should be adapted so that they become more appealing to extravert and agreeable students. The fact that these personality traits are dominant towards preferences and choices for STEM implies that there are many students who do have the cognitive capacity for STEM studies and occupations, but do not enroll in STEM studies because of their personality set. In other words, the loss in (cognitive) 'STEM talent' is especially large among this group. One should however be cautious to not lose the more introvert and less agreeable students by adapting too much to more extravert and agreeable students. A crucial question is whether this lack of appeal for the latter group is based on accurate beliefs about STEM studies and occupations, or on a stereotypical and inaccurate image. Our finding that, among girls, disagreeable and more open students are more likely to choose STEM suggests that female STEM students are those that are willing or able to go against the social norm. As such, these same social norms might be a barrier for other female students to enter STEM, also when they have the cognitive capacities to be successful in the field. A recent study by Breda, Grenet, Monnet, and Van Effenterre (2018) shows that the availability of more female role models in STEM occupations can help in changing these beliefs, thereby increasing (female) STEM enrollment.

This study has several limitations and therefore provides different angles for future research. Further research should aim to investigate whether the associations between personality traits and preferences for STEM are mostly based on the image they have about STEM or mostly on realistic views about STEM. Additionally, our more extended models typically rely on small sample sizes. It also remains challenging to disentangle the effects that personality can have on preferences and choices from the effects that preferences and choices have on personality. We have aimed to address this issue in this paper by using earlier measures of personality, but relying on comparatively smaller samples. While the overall patterns of results is robust, this issue deserves more attention in this literature. Additionally, our study cannot identify to what extent the different results between boys and girls are driven by stereotypical beliefs about STEM, which presents an important topic for future research. Finally, personality measures deserve a more central 
Table 9

Estimates for grade 6 personality measures (FIML with sample from Model 4).

\begin{tabular}{|c|c|c|c|c|c|c|c|c|c|}
\hline & \multicolumn{3}{|c|}{ Preference STEM occupation } & \multicolumn{3}{|c|}{ Preference STEM field of study } & \multicolumn{3}{|c|}{ S\&T track } \\
\hline & (4) & (5) & (6) & (4) & (5) & (6) & (4) & (5) & (6) \\
\hline Openness & $\begin{array}{c}0.155^{*} \\
(0.063)\end{array}$ & $\begin{array}{c}0.150 * \\
(0.063)\end{array}$ & $\begin{array}{l}0.175^{* *} \\
(0.064)\end{array}$ & $\begin{array}{c}0.053 \\
(0.039)\end{array}$ & $\begin{array}{c}0.052 \\
(0.039)\end{array}$ & $\begin{array}{c}0.050 \\
(0.040)\end{array}$ & $\begin{array}{l}0.256^{* *} \\
(0.091)\end{array}$ & $\begin{array}{l}0.275^{* *} \\
(0.092)\end{array}$ & $\begin{array}{l}0.295^{* *} \\
(0.093)\end{array}$ \\
\hline Conscientiousness & $\begin{array}{c}-0.031 \\
(0.064)\end{array}$ & $\begin{array}{c}-0.029 \\
(0.064)\end{array}$ & $\begin{array}{c}-0.038 \\
(0.064)\end{array}$ & $\begin{array}{c}-0.026 \\
(0.040)\end{array}$ & $\begin{array}{c}-0.024 \\
(0.040)\end{array}$ & $\begin{array}{c}-0.024 \\
(0.040)\end{array}$ & $\begin{array}{c}-0.083 \\
(0.096)\end{array}$ & $\begin{array}{c}-0.094 \\
(0.098)\end{array}$ & $\begin{array}{c}-0.099 \\
(0.098)\end{array}$ \\
\hline Extraversion & $\begin{array}{c}-0.177^{* *} \\
(0.060)\end{array}$ & $\begin{array}{c}-0.198 * * \\
(0.060)\end{array}$ & $\begin{array}{c}-0.209^{* * * *} \\
(0.060)\end{array}$ & $\begin{array}{c}-0.003 \\
(0.037)\end{array}$ & $\begin{array}{c}-0.006 \\
(0.037)\end{array}$ & $\begin{array}{c}-0.004 \\
(0.037)\end{array}$ & $\begin{array}{c}-0.230 * * \\
(0.087)\end{array}$ & $\begin{array}{c}-0.267 * * \\
(0.087)\end{array}$ & $\begin{array}{c}-0.260 * * \\
(0.087)\end{array}$ \\
\hline Agreeableness & $\begin{array}{c}-0.201 * * \\
(0.070)\end{array}$ & $\begin{array}{c}-0.213^{* *} \\
(0.070)\end{array}$ & $\begin{array}{c}-0.200 * * \\
(0.070)\end{array}$ & $\begin{array}{c}-0.062 \\
(0.045)\end{array}$ & $\begin{array}{c}-0.067 \\
(0.045)\end{array}$ & $\begin{array}{c}-0.066 \\
(0.045)\end{array}$ & $\begin{array}{c}-0.167 \\
(0.103)\end{array}$ & $\begin{array}{c}-0.179 \\
(0.104)\end{array}$ & $\begin{array}{c}-0.167 \\
(0.105)\end{array}$ \\
\hline Neuroticism & $\begin{array}{l}-0.050 \\
(0.062)\end{array}$ & $\begin{array}{c}-0.062 \\
(0.062)\end{array}$ & $\begin{array}{c}-0.059 \\
(0.062)\end{array}$ & $\begin{array}{l}-0.090 * \\
(0.039)\end{array}$ & $\begin{array}{l}-0.093^{*} \\
(0.039)\end{array}$ & $\begin{array}{l}-0.092^{*} \\
(0.039)\end{array}$ & $\begin{array}{l}-0.105 \\
(0.092)\end{array}$ & $\begin{array}{c}-0.101 \\
(0.093)\end{array}$ & $\begin{array}{c}-0.091 \\
(0.093)\end{array}$ \\
\hline Female & $\begin{array}{c}-0.873^{* * *} \\
(0.081)\end{array}$ & $\begin{array}{c}-0.860 * * * \\
(0.081)\end{array}$ & $\begin{array}{c}-0.825^{* * *} \\
(0.084)\end{array}$ & $\begin{array}{c}-1.227 * * * \\
(0.078)\end{array}$ & $\begin{array}{c}-1.230 * * * \\
(0.078)\end{array}$ & $\begin{array}{c}-1.238^{* * * *} \\
(0.080)\end{array}$ & $\begin{array}{c}-1.241 * * * \\
(0.130)\end{array}$ & $\begin{array}{c}-1.226^{* * *} \\
(0.131)\end{array}$ & $\begin{array}{c}-1.192^{* * *} \\
(0.134)\end{array}$ \\
\hline Atheneum & $\begin{array}{c}0.111 \\
(0.078)\end{array}$ & $\begin{array}{c}-0.006 \\
(0.083)\end{array}$ & $\begin{array}{c}0.104 \\
(0.087)\end{array}$ & $\begin{array}{c}0.100 \\
(0.084)\end{array}$ & $\begin{array}{c}0.048 \\
(0.091)\end{array}$ & $\begin{array}{c}0.035 \\
(0.096)\end{array}$ & $\begin{array}{c}0.114 \\
(0.120)\end{array}$ & $\begin{array}{l}-0.080 \\
(0.128)\end{array}$ & $\begin{array}{c}0.025 \\
(0.134)\end{array}$ \\
\hline Gymnasium & $\begin{array}{c}0.172 \\
(0.128)\end{array}$ & $\begin{array}{c}0.017 \\
(0.133)\end{array}$ & $\begin{array}{c}0.198 \\
(0.140)\end{array}$ & $\begin{array}{l}0.239 * \\
(0.105)\end{array}$ & $\begin{array}{c}0.186 \\
(0.110)\end{array}$ & $\begin{array}{c}0.160 \\
(0.125)\end{array}$ & $\begin{array}{c}0.222 \\
(0.185)\end{array}$ & $\begin{array}{l}-0.052 \\
(0.194)\end{array}$ & $\begin{array}{c}0.119 \\
(0.208)\end{array}$ \\
\hline Confidence in arithmetic & $\begin{array}{c}0.199 * * * \\
(0.021)\end{array}$ & $\begin{array}{c}0.191 * * * \\
(0.021)\end{array}$ & $\begin{array}{c}0.188^{* * *} \\
(0.021)\end{array}$ & $\begin{array}{l}0.041^{*} \\
(0.019)\end{array}$ & $\begin{array}{c}0.038 \\
(0.019)\end{array}$ & $\begin{array}{c}0.037 \\
(0.019)\end{array}$ & $\begin{array}{c}0.218^{* * *} \\
(0.034)\end{array}$ & $\begin{array}{c}0.202^{* * *} \\
(0.035)\end{array}$ & $\begin{array}{c}0.201 * * * \\
(0.035)\end{array}$ \\
\hline IQ figures & $\begin{array}{c}0.206 * * * \\
(0.039)\end{array}$ & $\begin{array}{c}0.174^{* * *} \\
(0.040)\end{array}$ & $\begin{array}{c}0.198^{* * *} \\
(0.041)\end{array}$ & $\begin{array}{c}0.066 \\
(0.039)\end{array}$ & $\begin{array}{c}0.058 \\
(0.039)\end{array}$ & $\begin{array}{c}0.058 \\
(0.039)\end{array}$ & $\begin{array}{c}0.266^{* * *} \\
(0.061)\end{array}$ & $\begin{array}{c}0.220 * * * \\
(0.063)\end{array}$ & $\begin{array}{c}0.240 * * * \\
(0.064)\end{array}$ \\
\hline IQ numbers & $\begin{array}{c}0.156^{* * *} \\
(0.041)\end{array}$ & $\begin{array}{l}0.120^{* *} \\
(0.042)\end{array}$ & $\begin{array}{l}0.129 * * \\
(0.042)\end{array}$ & $\begin{array}{c}0.032 \\
(0.042)\end{array}$ & $\begin{array}{c}0.020 \\
(0.043)\end{array}$ & $\begin{array}{c}0.017 \\
(0.043)\end{array}$ & $\begin{array}{l}0.234^{* *} \\
(0.067)\end{array}$ & $\begin{array}{l}0.182^{* *} \\
(0.068)\end{array}$ & $\begin{array}{l}0.187 * * \\
(0.069)\end{array}$ \\
\hline IQ words & $\begin{array}{c}0.002 \\
(0.033)\end{array}$ & $\begin{array}{c}0.000 \\
(0.034)\end{array}$ & $\begin{array}{c}0.005 \\
(0.034)\end{array}$ & $\begin{array}{c}0.003 \\
(0.034)\end{array}$ & $\begin{array}{c}0.004 \\
(0.034)\end{array}$ & $\begin{array}{c}0.004 \\
(0.034)\end{array}$ & $\begin{array}{c}0.017 \\
(0.052)\end{array}$ & $\begin{array}{c}0.016 \\
(0.052)\end{array}$ & $\begin{array}{c}0.022 \\
(0.052)\end{array}$ \\
\hline Mathematics test & & $\begin{array}{c}0.241^{* * *} \\
(0.052)\end{array}$ & $\begin{array}{c}0.266^{* * *} \\
(0.053)\end{array}$ & & $\begin{array}{c}0.083 \\
(0.056)\end{array}$ & $\begin{array}{c}0.083 \\
(0.056)\end{array}$ & & $\begin{array}{c}0.397^{* * *} \\
(0.082)\end{array}$ & $\begin{array}{c}0.427 * * * \\
(0.083)\end{array}$ \\
\hline Reading test & & & $\begin{array}{c}-0.212^{* * *} \\
(0.059)\end{array}$ & & & $\begin{array}{c}0.028 \\
(0.060)\end{array}$ & & & $\begin{array}{l}-0.197 * \\
(0.092)\end{array}$ \\
\hline $\mathrm{N}$ & 1110 & 1110 & 1110 & 481 & 481 & 481 & 1110 & 1110 & 1110 \\
\hline
\end{tabular}

Note: $*=$ significant at the .05 level. $* *=$ significant at the .01 level. $* * *=$ significant at the .001 level. All models include the full set of controls.

position in models of study choice in general, beyond the choice for STEM. The fact that cognitive measures are comparatively more important for STEM choice may be related to earlier findings in the literature that IQ becomes more important for job performance relative to personality when tasks get more complex. As such, relations between personality and study choice for other fields may be even stronger.

\section{References}

Almlund, M., Duckworth, A. L., Heckman, J., \& Kautz, T. (2011). Personality psychology and economics. In Handbook of the Economics of Education (Vol. 4, pp. 1-181). Elsevier.

Arcidiacono, P. (2004). Ability sorting and the returns to college major. Journal of Econometrics, 121(1-2), 343-375.

Arcidiacono, P., Hotz, V. J., \& Kang, S. (2012). Modeling college major choices using elicited measures of expectations and counterfactuals. Journal of Econometrics, 166(1), 3-16.

Atkinson, R., \& Mayo, M. (2010). Refueling the us innovation economy: Fresh approaches to science, technology, engineering and mathematics (STEM) education.

Balsamo, M., Lauriola, M., Saggino, A., et al. (2012). Personality and college major choice: Which come first? Psychology, 3(05), 399.

Barrick, M. R., \& Mount, M. K. (1991). The big five personality dimensions and job performance: a meta-analysis. Personnel Psychology, 44(1), 1-26.

Beffy, M., Fougere, D., \& Maurel, A. (2012). Choosing the field of study in postsecondary education: Do expected earnings matter? Review of Economics and Statistics, 94(1), 334-347.

Berger, M. C. (1988). Predicted future earnings and choice of college major. ILR Review, 41(3), 418-429.

Borghans, L., Golsteyn, B. H. H., Heckman, J. J., \& Humphries, J. E. (2011). Identification problems in personality psychology. Personality and Individual Differences 51 (Special Issue on Personality and Economics), 315-320. E. Ferguson, J.J. Heckman, and P. Corr, editors.

Breda, T., \& Napp, C. (2019). Girls' comparative advantage in reading can largely explain the gender gap in math-related fields. Proceedings of the National Academy of Sciences, 116(31), 15435-15440.

Breda, T., Grenet, J., Monnet, M., \& Van Effenterre, C. (2018). Can female role models reduce the gender gap in science? evidence from classroom interventions in French high schools. PSE Working Paper 2018-06.

Carnevale, A. P., Smith, N., \& Melton, M. (2011). Stem: Science technology engineering mathematics. Georgetown University Center on Education and the Workforce. CBS (2007). Studiekeuze sluit niet altijd aan op profiel. https://www.cbs.nl/nl-nl/nieuws/2007/20/studiekeuze-sluit-niet-altijd-aan-op-profiel.

Chen, P. D., \& Simpson, P. A. (2015). Does personality matter? Applying holland's typology to analyze students' self-selection into science, technology, engineering, and mathematics majors. The Journal of Higher Education, 86(5), 725-750.

Cobb-Clark, D. A., \& Tan, M. (2011). Noncognitive skills, occupational attainment, and relative wages. Labour Economics, $18(1)$, 1-13.

Costa, P. T., \& McCrae, R. R. (1992). Four ways five factors are basic. Personality and Individual Difference, 13(6), $653-665$.

Cunha, F., Heckman, J. J., \& Schennach, S. M. (2010). Estimating the technology of cognitive and noncognitive skill formation. Econometrica, 78(3), 883-931.

De Fruyt, F., \& Mervielde, I. (1997). The five-factor model of personality and holland's riasec interest types. Personality and Individual Differences, $23(1)$, 87-103.

Fricke, H., Grogger, J., \& Steinmayr, A. (2015). Does exposure to economics bring new majors to the field? Evidence from a natural experiment. Tech. rep. National Bureau of Economic Research.

Fuller, W. C., Manski, C. F., \& Wise, D. A. (1982). New evidence on the economic determinants of postsecondary schooling choices. Journal of Human Resources, 477-498. 
Gemici, A., \& Wiswall, M. (2014). Evolution of gender differences in post-secondary human capital investments: College majors. International Economic Review, 55(1), 23-56.

Goldberg, L. R. (1992). The development of markers for the big-five factor structure. Psychological Assessment, 4(1), 26.

Goldberg, L. R., Sweeney, D., Merenda, P. F., \& Hughes, J. E., Jr (1998). Demographic variables and personality: The effects of gender, age, education, and ethnic/ racial status on self-descriptions of personality attributes. Personality and Individual Differences, 24(3), 393-403.

Grove, W. A., Hussey, A., \& Jetter, M. (2011). The gender pay gap beyond human capital heterogeneity in noncognitive skills and in labor market tastes. Journal of Human Resources, 46(4), 827-874.

Groves, M. O. (2005). How important is your personality? Labor market returns to personality for women in the US and UK. Journal of Economic Psychology, 26(6), $827-841$.

Ham, R., Junankar, P. N., \& Wells, R. (2009). Occupational choice: Personality matters. IZA Discussion Paper 4105. Institute for the Study of Labor.

Heckman, J. J., Humphries, J. E., Urzua, S., Veramendi, G., et al. (2011). The effects of educational choices on labor market, health, and social outcomes (Unpublished manuscript). University of Chicago, Department of Economics.

Heckman, J. J., Stixrud, J., \& Urzua, S. (2006). The effects of cognitive and noncognitive abilities on labor market outcomes and social behavior. Journal of Labor Economics, 24(3), 411-482.

Holland, J. L. (1959). A theory of vocational choice. Journal of Counseling Psychology, 6(1), 35.

Holland, J. L. (1997). Making vocational choices: A theory of vocational personalities and work environments. Psychological Assessment Resources.

Humburg, M. (2017). Personality and field of study choice in university. Education Economics, 25(4), 366-378.

ICF, \& Cedefop (2015). EU skills panorama: STEM skills analytical highlight. Report prepared for the European Commission.

Jensen, R. (2010). The (perceived) returns to education and the demand for schooling. The Quarterly Journal of Economics, 125(2), 515-548.

Kahn, S., \& Ginther, D. (2017). Women and stem. Tech. rep. National Bureau of Economic Research.

Leslie, S.-J., Cimpian, A., Meyer, M., \& Freeland, E. (2015). Expectations of brilliance underlie gender distributions across academic disciplines. Science, 347(6219), $262-265$.

Liao, H.-Y., Armstrong, P. I., \& Rounds, J. (2008). Development and initial validation of public domain basic interest markers. Journal of Vocational Behavior, 73(1), $159-183$.

Lippa, R. A., Martin, L. R., \& Friedman, H. S. (2000). Gender-related individual differences and mortality in the Terman longitudinal study: Is masculinity hazardous to your health? Personality and Social Psychology Bulletin, 26(12), 1560-1570.

Long, M. C., Goldhaber, D., \& Huntington-Klein, N. (2015). Do completed college majors respond to changes in wages? Economics of Education Review, 49 , 1-14.

Lounsbury, J. W., Sundstrom, E., Loveland, J. M., \& Gibson, L. W. (2003). Intelligence, big five personality traits, and work drive as predictors of course grade. Personality and Individual Differences, 35(6), 1231-1239.

McCrae, R. R., Zonderman, A. B., Costa, P. T., Jr, Bond, M. H., \& Paunonen, S. V. (1996). Evaluating replicability of factors in the revised neo personality inventory: Confirmatory factor analysis versus procrustes rotation. Journal of Personality and Social Psychology, $70(3), 552$.

Mount, M. K., Barrick, M. R., \& Stewart, G. L. (1998). Five-factor model of personality and performance in jobs involving interpersonal interactions. Human Performance, 11(2-3), 145-165.

Nyhus, E. K., \& Pons, E. (2005). The effects of personality on earnings. Journal of Economic Psychology, 26(3), 363-384.

OECD. (2016). Education at a Glance 2016: OECD Indicators. Paris: OECD Publishing.

Poropat, A. E. (2009). A meta-analysis of the five-factor model of personality and academic performance. Psychological Bulletin, 135(2), 322-338.

Roberts, B. W., Kuncel, N. R., Shiner, R. L., Caspi, A., \& Goldberg, L. R. (2007). The power of personality: The comparative validity of personality traits, socioeconomic status, and cognitive ability for predicting important life outcomes. Perspectives in Psychological Science, 2(4), 313-345.

Rosenbloom, J. L., Ash, R. A., Dupont, B., \& Coder, L. (2008). Why are there so few women in information technology? assessing the role of personality in career choices. Journal of Economic Psychology, 29(4), 543-554.

Schwartz, J. B. (1985). Student financial aid and the college enrollment decision: The effects of public and private grants and interest subsidies. Economics of Education Review, 4(2), 129-144.

Techniekpactmonitor (2019). Techniekpactmonitor havo/vwo. https://www.techniekpactmonitor.nl/havovwo.

Van Eijck, C., \& de Graaf, P. M. (2004). The big five at school: The impact of personality on educational attainment. The Netherlands' Journal of Social Sciences, 40(1), $24-40$.

Vassend, O., \& Skrondal, A. (1997). Validation of the neo personality inventory and the five-factor model. can findings from exploratory and confirmatory factor analysis be reconciled? European Journal of Personality, 11(2), 147-166.

Wiswall, M., \& Zafar, B. (2014). Determinants of college major choice: Identification using an information experiment. The Review of Economic Studies, 82(2), 791-824. 